\title{
Budowa mostu na łodziach i przeprawa wojsk Władysława Jagiełły do Czerwińska w I 4 I0 roku
}

\author{
Construction of a Bridge on Boats and the Crossing \\ of Władysław Jagiełło's Army to Czerwińsk in 1410
}

Władysław Jagiełło and Witold Kiejstutowicz were preparing a war with the Teutonic Order. It was decided to build a bridge across the Vistula near Czerwińsk. The wood for building about 50 riverboats (punts) and spans had to dry for several months. The works which started in February 1409 in the Kozienice Forest were coordinated by Master Jarosław and Staroste Dobrogost the Black. Teams of boatbuilders, carpenters, blacksmiths and raftsmen made the elements of the bridge (boats, spans, anchors, iron buckles). The bridge was erected between Śladow and Czerwińsk on June 28-30, 1410. The barriers on the banks and the military forces ensured an uninterrupted march of the Polish army on June 30-July 3, comprising approx. 15,000 mounted knights, several hundred heavy tabor wagons, and several dozen cannons. The combined Polish and Lithuanian-Ruthenian armies departed from Czerwińsk for the war with the Teutonic Order. The bridge was dismantled, floated to Płock and rebuilt on the Vistula near Przypust on September 24-27, 1410 for the returning Polish army.

Keywords: Wladyslaw Jagiello, Radom Forest, Jedlnia, Kozienice, bridge construction: February 1409 - June 1410, riverboats, movable platforms, rafts, anchors, iron buckles, bridge assembly Czerwińsk: June 28-30, 1410, transfer of troops June 30-July 3, 1410, Master Jaroslaw, Staroste Dobrogost the Black

Słowa kluczowe: Władysław Jagiełło, Puszcza Radomska, Jedlnia, Kozienice, budowa mostu od lutego 1409 r., łodzie rzeczne, przęsła, tratwy, montaż mostu pod Czerwińskiem 28-30 czerwca; przejazd wojsk: 30 czerwca-3 lipca 1410 r., mistrz Jarosław, starosta Dobrogost Czarny

Podejmowany temat nie jest łatwy. Łączą się w nim: dzieje polskie i powszechne, historia gospodarcza i wojskowa, dzieje szkutnictwa i żeglugi, mostownictwa drewnianego, administracji i dworu królewskiego Jagiełły oraz inne wątki. Są to pola badawcze, które two- 
rzą całość w wydarzeniu, jakim był budowa rozkładanego mostu do przemarszu wojsk przez Wisłę. Badacze w tym przypadku dysponują ograniczoną liczbą źródeł: pisanych, archeologicznych i ikonograficznych.

Z pozoru najobfitsze są źródła archeologiczne. Jednak większość z nich stanowią destrukty drewniane bardzo różnych jednostek pływających. Wraków znalezionych nad Wisłą i w Małopolsce, datowanych na XV w., jest mało. Dzięki materiałom wykopaliskowym, zachowanym wrakom i pojedynczym elementom drewnianym, można odwołać się do ekspertyzy hydrologów, dendrologów i dendrochronologów, poddających specjalistycznej ocenie fakty materialne. Archeolodzy opracowali typologię średniowiecznych klamer szkutniczych. To daje możliwość przybliżonego datowania reliktów szkutnictwa, z dokładnością do kilku dziesięcioleci. Źródła pisane do tematu sprowadzają się do wzmianek w „Rocznikach” Jana Długosza, fragmentu w „Kronice konfliktu” oraz dokumentów różnego typu, dzięki którym ustalono daty, drogi przejazdów i miejsca pobytu króla Władysława Jagiełły podczas jego panowania. Źródła ikonograficzne (freski z XV w.) są skąpe, ale interesujące'.

Wybitni uczeni i teoretycy badań historycznych, Marceli Handelsman i Władysław Konopczyński, poświęcili w swoich podręcznikach dużo uwagi potrzebie i zasadom badania hipotez. Temat o zmontowaniu drewnianego mostu pod Czerwińskiem wymaga logicznego połączenia znanych ze źródeł faktów za pomocą hipotez, aby uzyskać pełniejszą rekonstrukcję wydarzeń2. Hipotetyczne rozumowanie powinno uwzględniać przede wszystkim wymiar czasu i ówczesne możliwości techniczne. Historyk może wskazać przypuszczalny przebieg wydarzeń: w określonym czasie i miejscu, określonym środowisku społecznym i ówczesnym centrum decyzyjnym, czyli dworze królewskim³. Zadanie to nie jest proste ponieważ całą akcję budowania mostu otoczono ścisłą tajemnicą dla uzyskania przewagi w pierwszej fazie wznawianej wojny z Zakonem Krzyżackim.

Wielka wojna Polski z Zakonem mogła rozpocząć się później. Walki i incydenty zbrojne na Żmudzi prowadziły do wojny, ale mogły jeszcze się przeciągać. Na początku 1408 r., po krzyżackiej prowokacji, czyli grabieży polskiego zboża wiezionego na Litwę statkami, Władysław Jagiełło podjął decyzję o walce. Zabór przez administrację krzyżacką 20 dużych statków, pełnych zboża, był wystarczającym powodem do podjęcia akcji zbrojnej.

1 Cronica conflictus Wladislai regis Poloniae cum Cruciferis anno Christi 1410, [w:] Monumenta Poloniae Historica, t. 2, wyd. A. Bielowski, Warszawa 1872, s. 897-904; J. Długosz, Roczniki czyli Kronika sławnego Królestwa Polskiego, ks. 10-11, Warszawa 1982; A. Gąsiorowski, Itinerarium króla Władysława Jagiełły: 1386 -1434, Warszawa 2015; W. Ossowski, Przemiany w szkutnictwie rzecznym w Polsce. Studium archeologiczne, Gdańsk 2010; J. Domosławski, Malarstwo ścienne na Pomorzu Wschodnim, [w:] Malarstwo gotyckie w Polsce. Synteza. Dzieje sztuki polskiej, t. 2, cz. 3, red. A.S. Labuda, K. Secomska, Warszawa 2004, s. 117-142.

2 M. Handelsman, Historyka, Warszawa 1928, cz. 1: Zasadnicze pojęcia historii, s. 1-38; cz. 2: Metodologia Historii, s. 202-246; W. Konopczyński, Historyka, Warszawa 2012: rozdz. 12: Rozwój i jego czynniki, s. 173-181; hasło: „hipoteza” wg indeksu.

3 T.M. Nowak, Uwagi o technice budowy mostów polowych w Polsce w XV do XVII wieku, "Studia i Materiały do Historii Sztuki Wojennej" t. 2, 1956, s. 345-387; S. Kuczyński, Wielka wojna z Zakonem Krzyżackim w latach 1409-1411, Warszawa 1980; Polska technika wojskowa do 1500 roku, red. A. Nadolski, Warszawa 1994; S. Jóźwiak, Wywiad i kontrwywiad w państwie zakonu krzyżackiego w Prusach, Malbork 2004; idem, Rozwój badań nad wielką wojną polsko-litewsko-krzyżacką (1409-1411) w historiografii ostatniego półwiecza, „Komunikaty Mazursko-Warmińskie" 2009, nr 2, s. 209-222; idem, K. Kwiatkowski, A. Szweda, S. Szybkowski, Wojna Polski i Litwy z Zakonem Krzyżackim w latach 1409-1411, Malbork 2010; S. Ekdahl, Grunwald 1410. Studia nad tradycją i źródłami, Kraków 2010; M. Jučas, Grunwald 1410, Kraków 2010; J. Tyszkiewicz, Geografia historyczna. Zarys problematyki, Warszawa 2014 
Zakon nie chciał udzielać wyjaśnień w tej sprawie. Król wysłał zboże z Kujaw, zapewne z Bydgoszczy. Mogły to być duże statki rzeczne typu reprezentowanego przez wraki z Elbląga (23 m długości i 4,5 m szerokości) ${ }^{4}$. Duże statki wiślane, z załogą 8-12 ludzi, mogły stanowić własność kupców czy bractwa przewoźników. W Toruniu już ok. 1300 r. zaś w Kwidzynie w 1390 r. istniały bractwa przewoźników, w rodzaju cechu żeglarzy. Handel wiślany z Gdańska do Krakowa jest poświadczony od XIII w. Ważnym towarem w tym handlu była sól, małopolska i ruska, od XV w. sprowadzana też przez Zakon z Europy zachodniej. Wiadomo, że interesy kupieckie łączyły odległe ośrodki miejskie, np. Nowy Sącz z Toruniem w 1407 r. $^{5}$

Koncepcja zbudowania mostu do przeprawy wojsk mogła powstać w gronie doradców królewskich, przede wszystkim kupców, przewoźników (cech włóczków krakowskich przed 1363 r.), ale również dowódców zajmujących się werbowaniem cudzoziemskich wojsk najemnych, zawodowych żołnierzy niemieckich czy czeskich.

Budowanie mostów opartych na łodziach poświadczone jest w Europie Zachodniej co kilka dziesięcioleci. Najbliższym czasowo przykładem europejskim było zbudowanie mostu na łodziach przy zdobywaniu Pizy przez wojska florenckie (w 1405 r. na rzece Arno). Były to lata kolejnych negocjacji i organizowania soborów w Italii, mających usunąć antypapieży. Wysłannicy polscy uczestniczyli w tych zabiegach. Wśród nich był biskup krakowski Piotr Wysz z Radolina. Należałoby ustalić, kto mu towarzyszył albo odwiedzał Italię w latach 1400-1409. Jeszcze uczestnicy soboru w Pizie (początek 26 marca 1409 r.) mogli widzieć lub dowiedzieć się o tej konstrukcji. Jednak wiadomość z Pizy była by przywieziona za późno, aby mogła spowodować rozpoczęcie budowy mostu w Puszczy Radomskiej ${ }^{6}$.

Należy z uwagą ale krytycznie uwzględnić informacje podane przez Długosza. Tekst swój pisał po 44 latach (lub później) od zmontowania mostu pod Czerwińskiem. Przy pisaniu „Roczników" wykazał się imponującą pracą, ale nie zawsze dokładnie znał fakty i nie zawsze był obiektywny?. Nawet rycerstwo polskie jadące z królem na drugi etap wojny z Zakonem nie wiedziało wiele (lub wcale) o przygotowywanym moście. Konkretna wiadomość Długosza o postawieniu solidnych barierek (na kobylicach) przed wjazdem na most mogła pochodzić od ojca lub stryja dziejopisarza. Tutaj oddziały jazdy stały i czekały przejazdu przez most w swojej kolejności. Tekst Długosza był ze zrozumiałych względów odpowiedzią na agresywną propagandę Zakonu. Dziejopis przedstawił sprawę zbudowania mostu na łodziach jako wyjątkowy sukces techniczny. Był to sukces, który kolejne pokolenia historyków, mało krytycznie, przyjmowały zgodnie z dosłowną wersją

4 W. Ossowski, Przemiany, s. 63-65, tutaj szczegóły.

5 J. Wyrozumski, Państwowa gospodarka solna w Polsce do schyłu XIV w., Kraków 1968; H. Samsonowicz, Gospodarka i społeczeństwo (XIII-początek XVI w.), [w:] Dzieje Mazowsza, t. 1, do 1526, red. H. Samsonowicz, Warszawa 2006, s. 339-394 i inne prace tego autora; A. Bartoszewicz, Handel solą na Mazowszu w XVI i XVI W., „Rocznik Mazowiecki” t. 18, 2006, s. 47-62, o wójcie Nowego Sącza, Mikołaju Tretszel, prowadzącym handel w 1407 r. z Toruniem i miastami Mazowsza s. 50.

6 J. Wyrozumski, O kongregacji włóczków krakowskich, „Małopolskie Studia Historyczne” t. 1, 1958, nr 1, s. 35-37. Przypuszczenie można sprawdzać, zob. K. Ożóg, Kościół katolicki w Królestwie Polskim w czasach Władysława Jagiełty, „Zeszyty Naukowe Uniwersytetu Jagiellońskiego. Prace Historyczne” t. 141, 2014, nr 2, s. 289-313.

7 J. Dąbrowski, Dawne dziejopisarstwo polskie (do 1480), Wrocław 1964, s. 214-238; E. Potkowski, Fikcja i historia u Długosza, „Przegląd Humanistyczny” 1987, nr 12, s. 47-63; M. Jučas, op. cit., s. 39-42. O polskiej propagandzie z 1410 r. i w następnym dziesięcioleciu: S. Ekdahl, op. cit., s. 157-179. 
Długosza. Historyk drogownictwa i historyk wojskowości wyrazili w trzeciej ćwierci XX w. powątpiewanie, czy „jedna zima” wystarczyła do realizacji zamierzenia. Byłby to termin nader krótki .

Tadeusz M. Nowak postanowił hipotetycznie ustalić dane techniczne dotyczące tej budowy, przyjmując jeden z możliwych wariantów. Podstawą rozumowania i obliczeń były mosty polowe z XVII i XVIII w., skonstruowane przez Krzysztofa Arciszewskiego i Józefa Jakubowskiego. Założenie, że most mistrza Jarosława z początku XV w. stanowi punkt wyjścia do dalszego rozwoju mostów typu łyżwowego przez 200-300 lat, jest mało sprawdzalne. Po prostu ten most nie posiada dokumentacji źródłowej. Proponowana budowa mostu, opartego na 168 łodziach, znajduje się w strefie prawdopodobieństwa. Wynika ono z faktu, że nie miały to być łodzie klepkowe, lecz łodzie dłubanki. Taką dokumentację rysunkową przedstawiono w publikacji Nowaka. Wszystkie czółna miały mieć długość (L) $5 \mathrm{~m}$, szerokość (B) 1,5 m i głębokość (H) $1 \mathrm{~m}$ od płaskiego dna do krawędzi burt ${ }^{9}$. Wykonanie przez pół roku ok. 170 dłubanek było możliwe, ale ryzykowne, ponieważ poddano by obróbce świeżo ścięte pnie. Czółna podlegałyby wysychaniu i pękaniu. Wzmacnianie listwami (z innych pni) nie musiało przynosić dobrych rezultatów. Tymczasem łodzie dźwigające most miały być niezawodne podczas pierwszego montowania, w końcu czerwca 1410 r. a także później, w trakcie następnych montaży. Dlatego należy teoretycznie rozważyć inne rozwiązania wymagające dostatecznie dużo czasu do realizacji przedsięwzięcia.

Hipotetycznie trafniej jest przyjąć, że budowa mostu mogła trwać najmniej rok, a wraz z niezbędnymi przygotowaniami i rekrutacją niezbędnych wykonawców przeszło rok. Uzgodnienia z mistrzem Jarosławem, dotyczące budowy, nastąpiły więc najpóźniej w lutym 1409 r., ponieważ król Władysław Jagiełło przebywał wówczas w Kozienicach (13 lutego 1409 r.) i Jedlni (13-19 lutego 1409 r.), cały tydzień. Podobnie postąpił w początku czerwca 1410 r. (Kozienice: 31 stycznia 1410 r., Jedlnia: 6 lutego 1410 r.) $)^{10}$. Przez cały okres swojego długiego panowania (1386-1434) Jagiełło przebywał w Kozienicach i Jedlni po tygodniu, tylko w lutym 1409 r. i lutym 1410 r. Mostu (łodzi i przęseł) nie można było zbudować od stycznia do początku czerwca 1410 r. Podstawowym uwarunkowaniem było zgromadzenie wystarczająco dużo odpowiedniego drewna, także przesuszonego. Cieśle i tracze montujący przęsła i pomosty oraz szkutnicy wykonujący łodzie klepkowe dobrze znali zasady stosowania odpowiednich gatunków drzew (dębu, quercus i sosny, pinus), a nawet selekcjonowania pojedynczych pni, właściwych do obróbki. W każdej stoczni gromadzono zapasy drewna; w Puszczy Radomskiej ich nie było ${ }^{11}$.

Przyjmując krytyczną ocenę fachowca, którego nie zadowalają prace z ostatniego półwiecza piszące o „moście Jagiełły”, formułujemy kilka dodatkowych uwag ${ }^{12}$. Ogra-

8 A. Rosset, Drogi i mosty w średniowieczu i czasach Odrodzenia, Warszawa 1974, s. 60; A. Nowakowski, Sprzęt taborowy, obozowy i przeprawowy, [w:] Polska technika wojskowa, Warszawa 1994, s. 256.

9 T.M. Nowak, Polska technika wojenna XVI-XVIII wieku, Warszawa 1970, s. 154-156.

10 A. Gąsiorowski, Itinerarium, Wstęp, s. 15-34, Święta Pańskie w praktyce objazdów króla Władysława Jagiełły, s. 154-164, Mapa szlaków objazdu, poza tekstem.

11 J. Kus, Materiały do dziejów szkutnictwa w XVI-XVIII wieku w "Aktach miasta Kazimierza Dolnego", "Kwartalnik Historii Kultury Materialnej" t. 32, 1984, nr 1, s. 23-38; W. Ossowski, M. Krąpiec, Niektóre zagadnienia szkutnictwa późnośredniowiecznego na przykładzie wraka z Kobylej Kępy, „Przegląd Archeologiczny” 2002, s. 85-101; A. Reszka, Wiślane statki i techniki nawigacyjne od XVI do XX wieku, Gdańsk 2012 (Prace Centralnego Muzeum Morskiego, Seria A, t. 13), s. 61 et passim.

12 B. Rymsza, O budowie repliki mostu Jagiełty, [w:] Wsparcie inżynieryjne w Wielkiej Wojnie z Zakonem Krzyżackim 1409-1411, Sesja z okazji 600-lecia bitwy pod Grunwaldem w 1410 roku, red. M. Białas, Warszawa 2010, 
niczają się one do przedstawienia pięciu wariantów, w jakich mógł być zbudowany ten most. Pierwszy, wg projektu Nowaka, przewidywał wykonanie czółen dłubanych w liczbie 168, połączonych parami, na których położono by 80 przęseł o długości 6 metrów. Drugi przedstawiła Barbara Rymsza, zmieniając koncepcję Nowaka na wykonanie katamaranów, utworzonych z łodzi klepkowych. Ich wymiary wskazują, że mogły by to być małe szkuty: 8-12 m długości, 2-2,5 m szerokości, 1 m wysokości. Długości przęseł nie podano, ponieważ nie zaproponowano szerokości katamaranu (zestawu 2 szkut). Rymsza dopuszcza rozwiązanie, że most składał się z paru segmentów przerzucanych między brzegiem, wysepkami i mieliznami w Wiśle ${ }^{13}$. Pomost miał mieć dźwigary rozmieszczone co $60 \mathrm{~cm}$. Te i inne szczegóły są hipotetyczne. Najbardziej kontrowersyjne jest założenie, że pomost na katamaranach był wykonany z nieokorowanych bali, pokrytych faszyną i nie posiadał barier (przy szerokości tylko 2,4 m). Oczywiście bariery mogły być zastąpione rozciągniętymi linami, ale po takim moście rycerze powinni jechać lub prowadzić konie pojedynczo. Ustawianie segmentów mostu między wysepkami należy wykluczyć. Most musiał być stabilny i przyjąć przejazd tysięcy konnych i kilkuset ciężkich wozów. Brakowało czasu na budowanie niezbędnych fragmentów jezdni na wysepkach i mieliznach.

Trzeci wariant wydaje się najbardziej prawdopodobny i właściwy do realizacji. Most mógł być oparty na szkutach (łac. scapha i in.), klepkowych łodziach, których nazwa upowszechniła się w Polsce w XVI w. Wczesne formy szkuty były podobne do rzecznej łodzi klepkowej znalezionej w Lądzie (z XIII w.) oraz statku z Pucka (ok. 1330 r.), ok. 15 m długości i 3,12 m szerokości ${ }^{14}$. Te łodzie, podobnie jak później w mostach łyżwowych, ustawiono zapewne szeregowo nad płynącym nurtem Wisły.

Brak wczesnych wzmianek wymieniających nazwę „szkuty” w Polsce przypomina inną trudność terminologiczną. Mostowcy używają technicznego określenia "most łyżwowy”, czyli most opierany na płaskodennych łodziach rzecznych, zwanych łyżwami. Ale nazwa "łyżwa” pojawia się w polskich źródłach pisanych dopiero w XVII w. Łyżwa nowożytna i bat zaczęły rywalizować ze staropolskimi szkutami i dubasami jako pojazdy bardziej ładowne. W związku z historią tych terminów „most Jagiełły” lepiej określić jako most na łodziach. Nie zachowała się żadna oryginalna nazwa z XV w. na ten typ okresowo stawianego mostu wspartego na płaskodennych łodziach rzecznych. Łodzie z czasów Jagiełły były znacznie węższe i smuklejsze od potwierdzonych dopiero od XVII w. łyżew ${ }^{15}$.

Most mógł zostać oparty także na płaskodennych statkach rzecznych z masztem, osiągających 30 m długości, biorąc pod uwagę zachowane wraki. Wymiary zachowanych statków wynosiły: w Elblągu 22, 25 m długości i 4,4 m szerokości (z końca XV w.), w Kobylej Kępie koło Sztutowa 21,7 m długości i 3,12 m szerokości (z końca XIII w.), w Pucku ok. 15 m długości i 3,12 m szerokości (ok. 1330 r.) i w Czersku 29,5 m długości i 7,4 m szerokości

s. 31-40. Wymienieni zostali: T.M. Nowak - 1956, J. Jankowski - 1973, B. Chwaściński - 1997, M. Czapski 2001, A. Stańczyk - 2009.

13 B. Rymsza, op. cit., s. 33 i 36.

14 W. Ossowski, Przemiany, s. 35-40. Por. A. Reszka, Żaglowce frachtowe z Czerwińska nad Wisłą, „Kwartalnik Historii Nauki i Techniki" t. 49, 2004, s. 69-112; idem, Wiślane statki i techniki nawigacyjne, s. 60-72; T. Ważny, Dendrochronologia obiektów zabytkowych w Polsce, Gdańsk 2001, s. 68.

15 B. Rymsza, op. cit., s. 34; S. Gierszewski, Statystyka żeglugi Gdańska w latach 1670-1815, Warszawa 1963, s. 264-265; A. Reszka, Wiślane statki, s. 72-74, myli się pisząc jakoby Długosz użył określenia „łyżwy”. Łyżwa miała np. rozmiary: $26,5 \mathrm{~m}$ długości i 6,30 m szerokości. 
(z połowy XVI w.). Freski z Torunia (połowa XV w.) i Kwidzyna (ok. 1420 r.) przedstawiają sylwetki statków rzecznych z żaglem, wiosłami pychowymi, dużym sterem wiosłowym i zadartym dziobem. Załoga statku składała się z 10-12 ludzi. Przedstawienia malarskie nie oddają wiernie proporcji, uwzględniając perspektywę dla patrzącego z dużej odległości. Zwłaszcza długość kadłuba nie jest proporcjonalna wobec żagla i przedstawionych postaci żeglarzy ${ }^{16}$.

Badacze szkutnictwa średniowiecznego nie biorą dostatecznie pod uwagę czasu potrzebnego do zbudowania łodzi klepkowej o średniej długości ok. $10 \mathrm{~m}$ i szerokości ok. $4 \mathrm{~m}$. Przyjęło się pisać, że wystarczało do tego kilku miesięcy, od stycznia do maja. Znane są także okresy wykonawcze z nowożytności, co nie wyjaśnia wszystkiego. Łatwe rozszczepianie pni dębowych na listwy i odpowiednie wyginanie klepek wykonywano rzeczywiście bez uprzedniego sezonowania. Już inaczej mogło być ze stępką: wątpliwe czy robiono ją z pnia ściętego 2-3 miesiące wcześniej. Mniejsze elementy konstrukcji łodzi czy statku, tzw. krzywulce na wręgi i inne części powinny być wysuszone. Szkutnicy mieli $z$ reguły zapasy odpowiedniego drewna, gotowego do użycia. W Puszczy Radomskiej nie było szkutników ani zapasów drewna. Przygotowanie surowca drzewnego do zbudowania konstrukcji nośnych (kratownic) i kilkudziesięciu przęseł wymagało pewnej liczby ekip cieśli i obróbki kilkuset metrów sześciennych drewna sosnowego. Jednoczesna budowa łodzi i przęseł tworzących ciągły pomost $(450-500 \mathrm{~m})$ mogła zostać zrealizowana najszybciej w przeciągu roku. W Jedlni i Kozienicach nie było żadnych rzemieślników przydatnych do budowy nawodnego mostu. We dworze królewskim mieszkała tylko czeladź i kucharze.

Mało prawdopodobna jest możliwość budowy mostu opartego na promach, płaskich jednostkach, bez burt i bez żagli. W średniowieczu były one stosowane do przepraw przez rzeki. W krzyżackich źródłach z XIV w. określane były jako Holzprom. Łatwo było połączyć je przęsłami. Powinny mieć dostateczną szerokość (np. 4-5 m) i dodatkowe pomosty, żeby utworzyć ciągły pomost przez poszczególne jednostki. Budowa 40 promów o $5 \mathrm{~m}$ szerokości i 50 przęsłami po $4 \mathrm{~m}$ długości mogła dać jezdnię biegnącą całą szerokością Wisły. Brak jednak wskazówek, że zastosowano takie rozwiązanie. Nie znaleziono także żadnego wraku średniowiecznego promu. Długosz wyraźnie zaś napisał, że most oparto na łodziach.

Na koniec warto zauważyć, że użytkowanie drewnianego mostu wymaga zadbania o jego nawierzchnię. Deski należało posypać ziemią. Konie i taborowe wozy mogły wówczas poruszać się po moście pewniej, bez poślizgu i potknięć. Deski przęseł były w ten sposób chronione przed szybkim zniszczeniem. Tysiące konnych wojowników, ciężkie wozy z artylerią z wysiłkiem ciągnięte przez tzw. woźniki (konie pociągowe), silnie zapierające się w nawierzchnię, poddawały ostrej próbie całą konstrukcję ${ }^{17}$.

16 W. Ossowski, Przemiany, s. 77-80; J. Domosławski, Malarstwo ścienne, s. 126. O składach drewna w stoczni elbląskiej: W. Ossowski, M. Krąpiec, Niektóre zagadnienia, s. 98-99.

17 B. Rymsza, op. cit., s. 36; także informacje innych ekspertów: K. Furtak, Mosty drewniane. Podręcznik dla studentów wyższych szkół inżynierskich, Kraków 2002; H. Zobel, Th. Alkhafaji, Mosty drewniane. Konstrukcje przełomu XIX i XX w., Warszawa 2006. 
Z Zakonem próbowano negocjować. Rozmowy osobiste Jagiełły, Witolda i wielkiego mistrza Ulricha Jungingen nie przyniosły rezultatów (6-8 stycznia 1408 r., Kowno). Przez styczeń 1408 r. Jagiełło przebywał w Wilnie (21 stycznia). Wspólnie z Witoldem ustalali z pewnością kolejność działań zbrojnych: najpierw na wschodzie, później na Żmudzi i wobec Zakonu. Jesienne działania zbrojne przeciw Moskwie zakończyły się pomyślnie dla Litwy. Nad rzeką Ugrą zawarł Witold 14 września 1408 r. układ pokojowy z Wasylem I, przywracający poprzedni stan rzeczy ${ }^{18}$. Wiadomość o zawarciu pokoju z Moskwą otrzymał zapewne Jagiełło we Lwowie ok. 4 października 1408 r. W końcu listopada (w Szydłowie jeszcze 28 listopada) pojechał król na Litwę i przebywał tam około miesiąca. Święta Bożego Narodzenia w Nowogródku (25 grudnia 1408 r.) i następny tydzień, w Wilnie lub Trokach (8 stycznia 1409 r.), spędzili Jagiełło i Witold razem. To był z pewnością okres podejmowania decyzji i sposobów działania na wojnie z Zakonem. Oczywiście po fiasku rokowań w Kownie (8-9 stycznia) obie strony rozpoczęły przygotowania do wojny polsko-litewsko-krzyżackiej. 6 sierpnia 1409 r. wielki mistrz Ulrich Jungingen wypowiedział formalnie wojnę Polsce; 16 sierpnia wojska krzyżackie wkroczyły na terytorium Królestwa Polskiego. Krzyżacy zdobyli zamki: Dobrzyń, Bobrowniki i Bydgoszcz. Jednakże Jagiełło zbrojnie odzyskał Bydgoszcz (6 października 1409 r.). Po szybkich negocjacjach zawarto zawieszenie broni 8 października 1409 r.: „do zachodu słońca” dnia 24 czerwca 1410 (święto Jana Chrzciciela). Przewidziano poddać spór pod sąd polubowny króla czeskiego Wacława ${ }^{19}$.

Tak więc w grudniu 1408 r. i styczniu 1409 r. Jagiełło z Witoldem omówili najważniejsze działania zbrojne w nadchodzącej wojnie z Zakonem. Sądząc z późniejszych wydarzeń, przewidziano również różne działania regionalne, koncentracje mniejszych ugrupowań nad granicami krzyżackimi, pozorowane przygotowania do przeprawy rzek, akcje równoczesne, polskie na Kujawach, a litewskie nad Niemnem itp. Już wtedy powinna zapaść decyzja o koncentracji obu armii sprzymierzonych nad środkową Wisłą. Dlatego jest zupełnie prawdopodobne, że do Kozienic (13 lutego 1409 r.) przyjechał Jagiełło z Litwy i przebywał w Jedlni cały następny tydzień (13-19 lutego) z podjętą wcześniej decyzją o budowie mostu na Wiśle, potrzebnego do przemarszu wojsk. To był wyjątkowo długi pobyt króla w Puszczy Radomskiej. Może wskazywać, że budowniczy i organizator, mistrz Jarosław, był już wytypowany i omawiano z nim etapy wykonania mostu. Wstępne przygotowania do realizacji projektu mogły się zresztą odbywać już dużo wcześniej, za radą wezwanych cieśli i szkutników. Budowa mostu, ze względu na potrzeby materiałowe, zgromadzenie odpowiedniego surowca, różnego gatunku drewna i należyte jego przesuszenie (tzw. sezonowanie), powinna trwać przeszło rok. Materiał niezbędny do budowy jednostek pływających oraz przęseł wymagał zgromadzenia, doboru, selekcji i przesuszenia. Nie było możliwe ani bezpieczne, ze względu na wymóg utrzymania prac w tajemnicy, skupowanie

18 J. Długosz, op. cit., ks. 10-11, ed. 1980, s. 24-26; L. Kolankowski, Dzieje Wielkiego Księstwa Litewskiego, t. 1, Warszawa 1930 , s. 86-87.

19 S. Kuczyński, op. cit., s. 129-152; S. Jóźwiak, K. Kwiatkowski, A. Szweda, S. Szybkowski, op. cit., s. 117-176; S. Jóźwiak, Negocjacje pokojowe w trakcie trwania pierwszej fazy wojny polsko-krzyżackiej (16 VIII-8 X 1409), „Roczniki Historyczne” t. 79, 2013, s. 57-72. 
materiału w wielu małych ośrodkach szkutniczych. Zasięg prac wymagał odpowiednio długiego czasu, to znaczy zapewne okresu od połowy lutego 1409 r. do połowy czerwca 1410 r. Zbudowanie kilkudziesięciu jednostek pływających i kilkudziesięciu przęseł powinno być przygotowywane przez zimę 1408/1409 r. i realizowane przez lato 1409 r. i zimę $1409 / 1410 \mathrm{r}$.

Decyzja o budowie mostu zapadła wcześniej, nie na naradzie w Brześciu Litewskim (ok. 30 listopada 1409 r.) czy rozmowach na łowach w Białowieży w pierwszych tygodniach grudnia. W Brześciu potwierdzono i ustalono miejsce oraz termin koncentracji pod Czerwińskiem. Realizacja tego podstawowego warunku wspólnego działania nie była uzależniona od postawienia mostu łyżwowego pod Czerwińskiem. Most jedynie ułatwiał i przyspieszył o 2-3 dni pełną koncentrację. Część zaopatrzenia, także armaty, mogła być spławiona statkami i odpowiednimi tratwami nawet do Płocka (co byłoby trochę ryzykowne), a z pewnością do Czerwińska czy Wyszogrodu. Bez mostu wojsko mogło przebyć Wisłę promami na dwóch sąsiednich przeprawach między Kamionem a Wyszogrodem, ale również ze Śladowa (też lewy brzeg Wisły) do Czerwińska. Brody umożliwiały również przekroczenie Wisły. Naszym zdaniem Jagiełło przyjechał z Brześcia i Białowieży nie z poleceniem rozpoczęcia budowy mostu, lecz na inspekcję, jak postępują prace. Wiadomo, że budowę koordynował i organizował starosta radomski Dobrogost Czarny ${ }^{20}$.

Przypominamy, że Jagiełło przyjechał do Kozienic (30 stycznia 1410 r.) i do Jedlni (6 lutego 1410 r.). Informacja Długosza o budowie mostu „przez całą zimę” jest prawdziwa, ale niepełna; już przed zimą 1409/1410 r. prace były poważnie zaawansowane.

W średniowieczu korzystano w centrum kraju z kilkunastu przepraw wpław przez Wisłę: w Zawichoście, Sieciechowie, Solcu, Janowcu i Kazimierzu, Puławach, Warszawie, Zakroczymiu, Wyszogrodzie, Płocku i Nieszawie. Najważniejsze przeprawy w XIV w., przez które wkraczały wrogie najazdy (np. Krzyżacy w 1331 r., Litwini w 1350 r.), znajdowały się w Płocku i Wyszogrodzie, mniej ważne pod Warszawą i w Solcu21. W XVII w. wchodziły w rachubę również płytkie brody i przejścia przy Czerwińsku, Nowym Dworze, Dęblinie i Włocławku22. Według Atlasu historycznego Polski: Mazowsze w drugiej połowie XVI w. przewozy na środkowej Wiśle funkcjonowały w: Czersku, Warszawie, Zakroczymiu, Wyszogrodzie i Płocku. W części II, objaśniającej mapy, zamieszczono krótki rozdział o drogach. Dołączono do niego mapkę Ważniejszych dróg na Mazowszu w XVI wieku. Z Sochaczewa poprowadzono trzy ważne drogi do przepraw na Wiśle: Łowicz - Młodzieszyn - Kamion - Wyszogród, Sochaczew - Mistrzowice - Kamion - Wyszogród i Sochaczew - Brochowo - Śladowo - Czerwińsk. Drogi do przewozu na Wiśle koło Czerwińska zaznaczono na obu brzegach, do Śladowa i nad brzeg oraz z Czerwińska też nad brzeg rzeki. W tekście objaśniającym o przewozie ze Śladowa do Czerwińska nie

20 J. Długosz, op. cit., ks. 10-11, sub anno 1409, ed. 1982, s. 52; A. Gąsiorowski, Itinerarium, s. 68.

21 K. Myśliński, Stałe punkty oporu nad Wisłą środkową i ich rola obronna do końca XIV w. [w:] Rola militarna Wisły w dziejach Polski, cz. 1: Od czasów piastowskich do 1864 r., red. K. Myśliński, Warszawa 1992, s. 41-47; K. Olejnik, Działalność militarna Polski w czasach Kazimierza Wielkiego, Poznań 1966, s. 84-89; M. Biskup, Wojny Polski z Zakonem Krzyżackim: 1308-1521, Gdańsk 1993, s. 21-35. Zob. T. Poklewski-Koziełł, Zamki królewskie i miasta obronne na drogach handlowych prowadzących przez Polskę nad Morze Battyckie w XIV i XV w., [w:] Studia o zamkach średniowiecznych, red. T. Poklewski-Koziełł, Warszawa 2012, s. 99-108.

22 M. Nagielski, Rola militarna Wisły w okresie "Potopu”, [w:] Rola militarna Wisły w dziejach, s. 59-129, mapa nr 1 s. 63; B. Dybaś, K. Walczak, Toruńska przeprawa i mosty na Wiśle, Toruń 1998. 
wspomniano ${ }^{23}$. Nawet jeżeli droga z Sochaczewa do Śladowa była drugorzędna, to przeprawa ze Śladowa istniała zapewne i wcześniej, w XV w.

Każdy okresowy bród i przeprawa miały swoją historię, najczęściej słabo znaną. Koryto Wisły zmieniało się często corocznie. Przeprawy łodzią czy promem ułatwiał szeroko rozlany nurt, płycizny, łachy i wysepki. Z Kamionu do Wyszogrodu przeprawa promowa była łatwa, ponieważ wody uchodzącej Bzury ułatwiały przewóz na wschodni brzeg. Trudniej było przeprawiać się z prawego na lewy brzeg Wisły. Lustracje dóbr królewskich, przeprowadzone w trzecim ćwierćwieczu XVI w., informują o występujących tutaj powodziach i długich podtopieniach niższych terenów nadbrzeżnych. Dokładniejsze mapy mówiące o zmianach koryta Wisły poniżej Warszawy dotyczą dopiero XIX w. ${ }^{24}$

Na kolejnych naradach Jagiełły z Witoldem plany koncentracji i ruchów wojsk ją osłaniających omawiano zapewne wielokrotnie. Most łyżwowy był przydatny, ale i bez niego połączenie wojsk planowano na prawym brzegu Wisły, powyżej ujścia Narwi. Istniejące przewozy i brody na Wiśle i Narwi zapewniały taką możliwość. Rozejm kończył się 24 czerwca, wobec tego koncentracja powinna nastąpić ok. 20 tego miesiąca; z pewnością liczono się z niezamierzonymi opóźnieniami niektórych oddziałów i nadchodzących zgrupowań. O zaletach koncentracji pod Czerwińskiem wypowiadali się liczni historycy (Otton Laskowski, Stefan Kuczyński, Marian Biskup i inni). W celu dezorientacji dowództwa krzyżackiego strona polsko-litewska wykonywała wiele zbrojnych demonstracji (koncentracja mniejszych zgrupowań wojsk, przemarsze) i pozorowała akcje zaczepne z Wielkopolski. Wywiad krzyżacki był stosunkowo rozbudowany, dlatego celowo rozpowszechniano mylne informacje o zamierzeniach Jagiełły i Witolda. Z wielu wskazówek można sądzić, że obie strony liczyły na dalsze rokowania. Znano praktykę działania króla węgierskiego Zygmunta Luksemburczyka, który w każdej nadarzającej się okazji starał się uzyskać dla siebie jakieś korzyści. Tak jak oczekiwano - albo nieoficjalnie wiedziano - przy pośrednictwie jego posłów dokonano przedłużenia rozejmu. W Wolborzu uzgodniono opóźnienie działań zbrojnych o całe 10 dni. Obie strony miały obecnie czas do 4 lipca ${ }^{25}$.

Wyznaczenie koncentracji miało jeszcze jeden aspekt, pomijany dotąd w rozważaniach. Jagiełło nie liczył na sprawne współdziałanie z książętami mazowieckimi, zwłaszcza z Siemowitem IV, księciem płockim. Obaj książęta wojnę Zakonowi wypowiedzieli późno i bez zapału. Jagiełło oparł się na współpracy z biskupem płockim Jakubem z Korzkwi Kurdwanowskim. Zapewnił on wykorzystanie Płocka jako bazy operacyjnej i miejsca groma-

23 Atlas historyczny Polski. Mazowsze w drugiej połowie XVI w., red. W. Pałucki, cz. 1: Mapy i plany, cz. 2: Objaśnienia, Warszawa 1973, mapa Ważniejszych dróg na Mazowszu w XVI wieku w cz. 2 po s. 120 oraz tekst objaśniający s. 119; Z biegiem Wisły, red. C. Kolago, Warszawa 1967, s. 360-362.

24 J. Tyszkiewicz, Klęski elementarne na Mazowszu w XVI-XVIII w., [w:] Dzieje Mazowsza, t. 2, 1527-1795 red. J. Tyszkiewicz, Pułtusk 2015, s. 297-299; Mapa Prus Południowych, oprac. D. Gilly, 1802-1803, skala 1:150 000, reprodukcja odcinka obejmującego dolinę Wisły, od Zakroczymia do Wyszogrodu i teren do Sochaczewa na południu. Zob. reprodukcję w opracowaniu: Kampinoski Park Narodowy: Dzieje Puszczy Kampinoskiej i okolic, t. 3, cz.1, red. P. Matusak, Izabelin 2005, s. 254-255. O zmianach koryta Wisły i powstaniu mielizn w początkach XX w. pod Czerwińskiem: M. Majewski, T. Tillinger, Roboty regulacyjne na Wiśle środkowej od 1919 do 1931, Warszawa 1932, s. 37-38, plansza II, plan 4, skala 1:100 000; Studia geograficzne nad aktywizacją małych miast, red. K. Dziewoński, Warszawa 1957, o Wyszogrodzie s. 31 i następne, plan miejsca dawnej przeprawy Wyszogród - Kamień s. 433.

25 J. Długosz, op. cit., ks. 10-11, sub anno 1410, s. 68-74; O. Laskowski, Grunwald, Londyn 1943, s. 71-105; S. Kuczyński, op. cit., s. 293-303; S. Jóźwiak. K. Kwiatkowski, A. Szweda, S. Szybkowski, op. cit., s. 211-237, 300-302. Zob. także: S. Jóźwiak, Wywiad i kontrwywiad. 
dzenia zaopatrzenia dla armii. Zabezpieczał również przeprawę przez Narew w Pułtusku, gdzie miasto i zamek były także jego. Własność biskupia i klasztorna Czerwińska dawała także wsparcie dla koncentrujących się i obozujących wojsk. Biskup Jakub z Korzkwi popierał z przekonaniem działania króla, czemu dał wyraz w kazaniu do zgromadzonego rycerstwa w kościele opactwa w Czerwińsku (2 lipca 1410 r. $)^{26}$.

Król Władysław Jagiełło miał też kontakt osobisty lub pośredni z klasztorem czerwińskim. Przebywał tutaj kilkakrotnie; pierwszy raz właśnie w dniach 30 czerwca-3 lipca 1410 r. a później w 1419 r. i 1422 r. W pierwszym okresie rządów Jagiełły w jego otoczeniu znajdował się Andrzej Ciołek Starszy (zm. 1396 r.) i jego syn Andrzej z Żelechowa. Ten ostatni utrzymywał stosunki z opactwem czerwińskim oraz parą królewską, Jadwigą i Jagiełłą w Krakowie. Śladów i Wola Śladowska, położone przy przeprawie przez Wisłę do Czerwińska, stanowiły pod koniec XIV w. własność rodu Gozdawów. Świętosław Mzurka (zm. 1421 r.) z Bielaw pod Warszawą, był przed 1400 r. kuchmistrzem na dworze króla Jagiełły w Krakowie. Później wrócił na Mazowsze i przejął część dóbr rodowych, w tym także nadwiślański Śladów ${ }^{27}$. Niewykluczone, że mistrz Jarosław lub wysłani przez niego współpracownicy przyjeżdżali i zatrzymywali się w Śladowie, żeby zrobić wstępne pomiary w terenie. Należało wyznaczyć miejsce (wbić słupy) i sprawdzić dojazd z pól do samego nurtu rzeki w miejscu planowanej przeprawy w czerwcu przed wznowieniem wojny.

O warsztatach szkutniczych nad Wisłą z XIV-XV w. nie wiemy prawie nic poza faktem, że były rozproszone w różnych miejscowościach, najczęściej w pobliżu działających portów lub nadbrzeży przystosowanych do ładunku i rozładunku towarów ${ }^{28}$. Miejsce małych stoczni określano terminem „przy palu”. Około 1400 r. porty nad Wisłą środkową znajdowały się w: Solcu, Czersku, Warszawie, Zakroczymiu, Czerwińsku, Wyszogrodzie i Płocku. Dołączyć do nich należy jeszcze Łowicz i Pułtusk, aktywnie uczestniczące w handlu wiślanym ${ }^{29}$. Sprowadzenie stamtąd wszystkich specjalistów do budowania mostu w Kozienicachw 1408-1410 r. nie wchodziło jednak w rachubę. Byli oni poddanymi książąt mazowieckich oraz znajdowali się pod stałą obserwacją wywiadu krzyżackiego i mieszczan toruńskich.

Należało więc zgromadzić bez rozgłosu, najpewniej z Małopolski, odpowiednich wykonawców, najlepiej działające już zespoły szkutników oraz cieśli, traczy, pracowników pomocniczych i kowali. Klepki do poszycia zewnętrznego wszystkich jednostek pływają-

26 J. Długosz, op. cit., s. 76; zob. też: S. Pazyra, Geneza i rozwój miast mazowieckich, Warszawa 1959, o Czerwińsku s. $62-63,74,85,113-114$ i in.

27 A. Gąsiorowski, Itinerarium, s. 70, 90, 96; K. Pacuski, O rodzie Gozdawów na Mazowszu w XIV-XV w. i jego tradycjach, [w:] Kultura średniowiecza i staropolska. Studia ofiarowane A. Gieysztorowi, Warszawa 1991, s. 655-665; M. Wilska, Mazowieckie środowisko dworskie Janusza Starego. Studium społeczne, Warszawa 2012, s. 85; K. Pacuski, Wspótpracownicy książąt mazowieckich w ziemi warszawskiej w XIV w., [w:] Początki Warszawy. Spojrzenie po 700 latach, red. H. Rutkowski, Warszawa 2015, s. 64.

28 P. Smolarek, Stan i perspektywy badań nad rozwojem szkutnictwa w Polsce (do końca XVIII w.), „Kwartalnik Historii Kultury Materialnej" t. 7, 1959, nr 2, s. 229-267, zwłaszcza s. 231-232; W. Ossowski, Przemiany w szkutnictwie, nadal szczupła podstawa źródłowa. Analogie: J. Litwin, Polskie szkutnictwo ludowe XX wieku, Gdańsk 1995.

29 Z. Morawski, O spławie wiślanym i przyczynach wojny 1409-1411, „Kwartalnik Historyczny” t. 95, 1988, nr 1, s. 107-110; idem, Handel miast nadwiślanego Mazowsza do końca XVI w., [w:] Studia nad ośrodkami miejskimi w dorzeczu środkowej Wisły, red. J. Łukasiewicz, Warszawa 1996, s. 7-31. W nadwiślańskich miastach Mazowsza nie było w 2 połowie XV w. cechów szkutników czy cieśli: H. Samsonowicz, Gospodarka i społeczeństwo. XIII-pocz. XVI w., [w:] Dzieje Mazowsza t. 1, do 1526, red. A. Gieysztor, H. Samsonowicz, Pułtusk 1994, s. $268-269$. 
cych powinny być przygotowane metodą darcia, czyli rozczepiania pni klinami. Jednakże kilkaset metrów sześciennych drewna (nie próbujemy określić liczby), belek i desek niezbędnych do przygotowania przęseł i całej jezdni mostu mogło dla usprawnienia pracy podlegać obróbce metodą piłowania przez traczy. Podkreślamy, że kluczowe było zgromadzenie odpowiednich ilości wybranych asortymentów drewna i jego należyte wysuszenie. Część przeznaczona na budowę przęseł powinna podlegać sezonowaniu: przez parę miesięcy przebywać na wolnym powietrzu, ale osłonięta od opadów, np. w otwartych szopach. Duże masy drewna zgromadzono dopiero po wytypowaniu w lesie odpowiednich drzew, ścięciu i przewiezieniu. Dalsze odległości ścięte pnie mogły przebyć spławione rzekami Zagożdżanką i Radomierzą, przewiezione saniami albo przeciągnięte przez woły. Najpewniej część budulca ścięto wiosną (marzec-maj 1408 r.), pozostałą zaś masę zapewne zimą i wiosną $1409 \mathrm{r}$.

Wiadomo, że w XVII w. podobny most składany budowano w stoczni gdańskiej półtora roku ${ }^{30} .200$ lat wcześniej w Puszczy Radomskiej nie mogło to nastąpić czterokrotnie szybciej. Budowano przecież z belek i grubych desek kilkadziesiąt jednostek pływających, mających unieść ciężką jezdnię oraz wytrzymać przejazd dużego taboru i tysięcy oddziałów jazdy (przyjmujemy ciężar jezdnego z koniem na ok. $750 \mathrm{~kg})^{31}$. Szerokość Wisły pod Czerwińskiem w 1410 r. szacować można na 450-500 m (w 1804 r. wynosiła 450 m). Prawy, wyższy brzeg Wisły pod Czerwińskiem umożliwiał skrócenie pomostów (na kozłach i palach) prowadzących z mostu. Lewy, czyli zachodni brzeg był i pozostał nizinny, więc do nurtu prowadzić musiały dłuższe pomosty nad łąką, łachą czy grząskim wybrzeżem. Na urwistym, prawym brzegu zbudowano Zakroczym (lokacja w 1422 r.). Osiem tysięcy kroków dalej z biegiem rzeki znajdował się Czerwińsk, z murowanym klasztorem augustianów ${ }^{32}$.

Hipoteza Nowaka o wykonaniu 168 łódek łączonych parami wzdłuż sznura rozciągniętego przez Wisłę jest trudna do obrony. Musiano zbudować raczej masywne jednostki pływające, na których można było zmontować przęsła i jezdnie. Nie sposób ustalić na pewno, czy były to szkuty, czy płaskodenne promy. Wszystkie te typy statków mogły poruszać się dzięki wiosłom i stawianemu masztowi. Zakładając, że szerokość łodzi wynosiła $5 \mathrm{~m}$, do zmontowania mostu powinno ich być ok. 50. Nie będziemy obliczać nośności przęseł mostu. Wystarczy przyjąć założenie o pojedynczym (z dużymi odstępami) przejeżdżaniu ciężkich wozów taborowych (każdy 600 kg ładunku); z 3 końmi (koń 600-650kg) i 4 ludzi (po 80 kg bez uzbrojenia), razem ok. 2720-2870 kg obciążenia. Wóz taborowy (tzw. skarbowy) wypełniony żywnością i sprzętem, miał przejechać 650 m (500 m nad wodą), jezdnią utworzoną z kolejnych przęseł pomiędzy ustawionymi w szereg łodziami. Każde przęsło wsparte na łodziach (zapewne szkutach) składało się prawdopodobnie z 4 moc-

30 T.M. Nowak, Uwagi o technice, s. 381-383.

31 Z obliczeń Nowaka i Łapkina można przywołać kilka orientacyjnych danych: koń miał ważyć średnio 650 kg, wojownik $100 \mathrm{~kg}$, masa potrzebnego drewna budulcowego najmniej $500 \mathrm{~m}^{3}$, ibid., s. 352-356. Por. też: B. Rymsza, op. cit., s. 33. Obciążenie każdego 6-metrowego przęsła miało wynosić: dla kawalerii 1680 kg, taboru $2100 \mathrm{~kg}$ i artylerii również $2400 \mathrm{~kg}$.

32 S. Pazyra, Geneza i rozwój miast mazowieckich, s. 62-63, 113 i in.; idem, Najstarszy opis Mazowsza Jędrzeja Święcickiego, Warszawa 1974, tekst źródłowy: s. 171-172; E. Falkowski, Wisła Mazowiecka, [w:] Wisła. Monografia rzeki, red. A. Piskozub, Warszawa 1982, s. 141-146; Mapa Prus Południowych, oprac. D. Gilly, 1802-1803, 1:150.000; M. Majewski, T Tillinger, op. cit., s. 37-38 i plansza II, 1:100.000. 
nych belek dębowych i grubych desek położonych w poprzek jezdni. Cała jezdnia musiała wytrzymać przejazd ok. 600 wozów, armat, prochu i amunicji złożonej z kamiennych kul armatnich.

W rezultacie wodowanie na przykład 50 płaskodennych łodzi (np. $15 \mathrm{~m}$ długości, $3 \mathrm{~m}$ szerokości), położenie na ich pokładach jezdni (belki nośne, deski poprzeczne) długiej w sumie na $150 \mathrm{~m}$ oraz dwa razy tyle niezbędnych przęseł z jezdniami (50 po $6 \mathrm{~m}$, razem $300 \mathrm{~m}$ ) oraz trapów wprowadzających z brzegu na konstrukcję pływającą nie mogło być wykonane w 6 miesięcy. Trzeba było także przygotować długie barierki (na kozłach) na obu brzegach dla utrzymania porządku przy przekraczaniu mostu. Te barierki brzegowe nazwał Długosz „kobylicami”33. Prócz tego należało wykonać setki wioseł pychowych i odpowiednią liczbę masztów.

W Krakowie cech włóczków zrzeszał od połowy XIV w. (pierwsza wzmianka w 1363 r.) licznych żeglarzy i flisaków, zajmujących się transportem wodnym. Koło Zwierzyńca znajdował się duży port rzeczny. Z tego środowiska wytypowano zapewne mistrza Jarosława. W Krakowie mistrzowie szkutnictwa poświadczeni są w źródłach pisanych dopiero w XVI w., ale klepkowe statki rzeczne budowano przecież od XII w. Jest prawie pewne, że imienne nadania dla Jarosława i Dobrogosta Czarnego od króla Jagiełły (jesień 1410 r.) były nagrodą za ich pracę przy budowie mostu ${ }^{34}$.

Wybrane zespoły szkutnicze zgromadzono w Puszczy Radomskiej i zapoznano z ogólnym planem budowy flotylli mostowej. Na przeszło rok część wykonawców mostu musiała przenieść się w okolice Kozienic i dla zachowania tajemnicy ograniczyć kontakt z rodzinami. Mistrz Jarosław uformował najmniej 10 zespołów szkutniczych, zakładając, że każdy zespół mógł zbudować 5 łodzi tzn. szkut. Zespołów było zapewne więcej. Drwale, cieśle i tracze powinni przystąpić do przygotowania odpowiednich asortymentów drewna wcześniej, ale musieli mieć orientację w zapotrzebowaniu szkutników i planach konstruowania przęseł. Wcześniej, po odpowiednich obliczeniach, do pracy przystąpiły kuźnice i zespoły kowali. Każda szkuta dla stabilnego umocowania w nurcie Wisły powinna dysponować 4 kotwicami. Piąta kotwica, zapasowa, mogła być również w wyposażeniu, ponieważ planowano przecież spływ do Płocka i ponowne ustawianie mostu. Należało zapewne wykonać ok. 250 kotwic. Nie ma wzmianek o łańcuchach, ale wolno przypuszczać, że wykonano dwa długie łańcuchy, w sumie ok. 1000 m. Łańcuchy rozciągnięte od brzegu do brzegu dawały pewność połączenia łodzi i wykonania ewentualnych działań awaryjnych. Solidne wykonanie szkut wymagało łączenia desek i klepek poszycia kutymi żelaznymi klamrami szkutniczymi o długości $20-30 \mathrm{~cm}$. Statek wiślany z Czerska, zbudowany 70 lat później, ze stępką i długi ok. 30 m, posiadał 3150 klamer wzmacniających. Budowa szkuty wymagała zapewne użycia najmniej 1500 klamer szkutniczych. Część połączeń, zwłaszcza z wręgami, łączono drewnianymi czopami35.

33 Długosz o barierkach: ks. 10-11, wyd. 1982, s. 76: źle przetłumaczone, źle objaśnione w przypisie nr 143. Zob. B. Linde, Słownik języka polskiego, t. 2, Lwów 1855, hasło „Kobyła”, s. 392.

34 J. Wyrozumski, O kongregacji włóczków krakowskich, s. 35-37; A. Gąsiorowski, Nad nowym wydaniem „Roczników” Jana Długosza, „Przegląd Historyczny” t. 74, 1983, nr 1, s. 120; Zbiór dokumentów małopolskich, t. 6, wyd. S. Kuraś, Kraków 1972, nr 1735 (dla Jarosława), nr 1754 (dla Dobrogosta).

35 W. Ossowski, Przemiany w szkutnictwie, passim; analogie starsze i młodsze: P. Smolarek, Zabytki szkutnictwa skandynawskiego, Gdańsk 1963; idem, Stan i perspektywy, s. 232-238; J. Litwin, Polskie szkutnictwo ludowe; idem, Sztuka rzecznego szkutnictwa, „Rzeki” t. 9, 2000, s. 217-263. O statku typu „szkuta”: P. Smolarek, Morska technika wojskowa. Od przełomu XII i XIII w. do poł. XV w., [w:] Polska technika wojskowa, s. 366-367. 
Sądzimy, że należy przyjąć racjonalne działania mistrza Jarosława. Mógł on osobiście lub przez wysłanych współpracowników dokonać wstępnych pomiarów w terenie. Należało wytypować miejsce i zlokalizować dojazdy z pól do samego nurtu rzeki. Na pewnych odcinkach należało umocnić nawierzchnię drogi dla setek ciężkich wozów przez wyłożenie jej dranicami czy balami. W maju i początkach czerwca obserwowano intensywność opadów w Karpatach i ogólnie w Małopolsce oraz wysokość stanu wody w Wiśle. W czerwcu stan wody był (i bywa) z reguły wyższy od średniej, ale zdarzały się także nagłe powodzie ${ }^{36}$. Przy wyższej wodzie napór na most był większy oraz potrzeba było większej liczby przęseł i szkut. Wysoka woda mogła utrudnić przeprawienie się wojsk na prawy brzeg Wisły.

W maju albo już w kwietniu 1410 r., na dostatecznie rozległej przestrzeni wodnej na Wiśle przeprowadzono prawdopodobnie próby montażu kilku gotowych „przęseł”, zestawów przeprawowych. Tylko u ujścia rzeki Zagożdżanki można było dokonać takich prób, na mniejszą skalę. Należało ustawić obok siebie szkuty na kotwicach i zmontować pomosty wjazdowe z brzegu oraz jezdnię przechodzącą przez ich pokłady na drugą stronę. Bez wykonania prób ryzyko poważnych opóźnień pod Czerwińskiem byłoby zbyt duże. Sprawne ustawienie mostu wymagało wcześniej próbnego montażu jego części i sprawdzenia możliwości ich szybkiego połączenia. Wyprowadzanie obciążonych szkut i jednostek pomocniczych z Kozienic na nurt Wisły, później zaś spływ całej flotylli przeszło $140 \mathrm{~km}$ z biegiem rzeki pod Czerwińsk, musiało trwać więcej niż dobę. Most powinien stanąć ok. 24 czerwca, gdyż wtedy kończył się rozejm i nie można było przewidzieć, czy nastąpi jego przedłużenie i na jak długo.

W gotowości do spływu od ok. 20 czerwca musiała znajdować się duża grupa (kilkuset) budowniczych: cieśli i szkutników, oraz żeglarzy. O przedłużeniu rozejmu (26 czerwca) król zawiadomił starostę Dobrogosta Czarnego i mistrza Jarosława ${ }^{37}$. Musieli oni zadecydować kiedy wyruszą. Najwcześniej mogli odpłynąć z Kozienic o świcie 27 czerwca (piątek), kiedy Jagiełło był w Lubochni ${ }^{38}$. Szkutami i jednostkami towarzyszącymi kierowali doświadczeni flisacy i żeglarze. Przy umiejętnym sterowaniu mogli wykorzystać żagle. Cały dzień trwał spływ wszystkich 50 szkut i tratw pomocniczych (ok. 10) z gotowymi odcinkami jezdni (zapewne przybite deski na belkach-legarach) i innymi materiałami. Najwcześniej pod wieczór 27 czerwca można było rozpocząć montaż mostu w wyznaczonym miejscu. Niektóre jednostki (promy i tratwy) płynęły zapewne wolniej i dotarły dopiero przed nocą. Montaż kontynuowano przez całą sobotę (28 czerwca) i zapewne niedzielę (29 czerwca). Zawieszono sznur i wbito kafarami słupy, aby równo zakotwiczyć szkuty. Być może powiązano je łańcuchem (lub dwoma) w poprzek nurtu

36 B. Chlebowski, Wisła, [w:] Słownik Geograficzny Królestwa Polskiego, t. 13, Warszawa 1893, s. 589-591. Wysoki stan wody z reguły: wiosną, w czerwcu (tzw. świętojanka), jesienią (tzw. michałówka), czyli ok. 24. czerwca i 29 września, J. Kobendzina, Powodzie na Wiśle w okolicach Warszawy, „Gospodarka Wodna” t. 14, 1954, nr 4, s. 129-131, dane z 1813-1870, Leoncin koło Zakroczymia. Por.: Dorzecze Wisty. Monografia powodzi: maj-czerwiec 2010, red. M. Maciejewski i in., Warszawa 2011, o dawnych powodziach: s. 83-85; J. Stachý, B. Fal, I. Dobrzyńska, J. Hołdakowska, Wezbrania rzek polskich w latach 1951-1990. Materiały Badawcze, Warszawa 1996 (Hydrologia i Oceanografia, nr 20).

37 S. Kuczyński, op. cit., s. 340. Przejazd negocjatorów węgierskich od wielkiego mistrza Ulricha do króla Jagiełły w Wolborzu oraz gońca z Wolborza do Kozienic musiał trwać blisko 2 dni. Polecenie do Kozienic mogło dotrzeć rankiem 26 czerwca, bardzo wątpliwe, żeby wcześniej.

38 A. Gąsiorowski, Itinerarium, s. 70. 
Wisły. Korzystając z tratw zaczęto układać jezdnię. Zapewne pracę rozpoczęto jednocześnie z obu brzegów.

Zmontowano wjazdy z brzegów na najbliżej stojące promy. Wtedy można było układać dalej jezdnię z przęseł. Oceniamy, że przęsła były przygotowane do położenia i wnoszone albo z lądu, albo z tratw, które stały obok. Na pokładach szkut mogły znajdować się gotowe pomosty z belek, służące jako podstawa dla układanych jezdni. Dla łatwiejszego przesuwania i montażu przęseł nie miały zapewne w transporcie przybitych wszędzie desek. Dopiero na pływającej konstrukcji, falującym moście, uzupełniano jezdnię brakującymi deskami tworząc szczelną powierzchnię, po której miały poruszać się konie i wozy. Nie można wykluczyć stosowania prostych urządzeń do podnoszenia ciężarów (liny i wielokrążki na stojakach, umieszczone na tratwach). Stawianie mostu ukończono w południe 30 czerwca (poniedziałek). Nie ma pewności czy przestrzegano odpoczynku w niedzielę. Stawianie mostu trwało więc przez sobotę, niedzielę i ranek poniedziałkowy $(28,29$

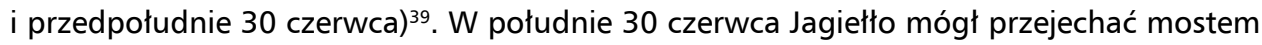
do Czerwińska.

Koncentracja wojsk litewskich i posiłkowych, mających walczyć pod dowództwem księcia Witolda, odbywała się na początku czerwca 1410 r.; w późniejszej fazie między Narwią i Bugiem, zapewne w okolicach Drohiczyna (11-24 czerwca). Następnie Litwini ruszyli do przeprawy przez Narew koło Pułtuska. W niedzielę, 29 czerwca Witold przysłał gońca do Jagiełły, przebywającego już w miejscowości Kozłów w pobliżu Sochaczewa ${ }^{40}$, prosząc o eskortę od Pułtuska do Czerwińska. Witold był ostrożny: przedłużenie rozejmu nie dotyczyło Litwy, wojska litewskie znajdowały się na terytorium księstwa mazowieckiego, nie miał pewności, czy książę Janusz wypowiedział już oficjalnie wojnę Krzyżakom. Chciał jechać najwygodniejszą drogą, korzystając z przewodników. Jego armia była liczebna i prowadziła także tabory. Król Władysław Jagiełło przejechał po moście zapewne koło południa 30 czerwca w poniedziałek. Po powitaniu Jagiełły i Witolda rozbito wspólny obóz pod Czerwińskiem. W tym czasie, po południu 30 czerwca i w następne dwa lub trzy dni przez most przejechały tabory, armaty i kolejne grupy wojsk. Wspólny obóz połączonych wojsk - królewskich z Polski, litewskich i posiłkowych oraz mazowieckich (częściowo) - stał pod Czerwińskiem od popołudnia 30 czerwca do południa 3 lipca. Nastrój rycerstwa do zdecydowanej walki podniosło kazanie biskupa płockiego Jakuba z Korzkwi, wygłoszone w przyklasztornym kościele w Czerwińsku, w święto Nawiedzenia NM Panny 2 czerwca 1410 r. Kazanie wygłoszone po polsku poświęcone było pojęciu wojny sprawiedliwej, według tez głoszonych później przez Pawła Włodkowica i Stanisława ze Skalbmierza ${ }^{41}$.

Już nazajutrz 3 lipca (czwartek) połączone armie ruszyły na północ. Należy przyjąć, że tabory, armaty, piechota i duża część jazdy przeprawiła się przez most. Niewykluczone jednak, że część jazdy polskiej przekroczyła Wisłę tradycyjnie brodami, pod Zakroczymiem, Czerwińskiem i z Kamienia do Wyszogrodu. W najbliższych dniach - 4 (piątek) lub 5 lipca

39 Wiadomość Długosza o postawieniu mostu „w pół dnia” mogła powstać nie tylko z przyczyn propagandowych. Mogła pochodzić z otoczenia Jagiełły, czekającego w Kozłowie pod Sochaczewem. Informator mógł uważać, że w niedzielę nie pracowano i powiedział, że most musiał być szybko zmontowany, ponieważ król niecierpliwie czekał na spotkanie $z$ Witoldem.

40 J. Długosz, op. cit., ks. 10-11, sub anno 1410, s. 75; S. Kuczyński, op. cit., s. 340-341; K. Kwiatkowski, Koncentracja; S. Jóźwiak, K. Kwiatkowski, A. Szweda, S. Szybkowski, op. cit., s. 238-266, 303-305.

41 Długosz, op. cit., s.76. 
(sobota) zaczęto demontować most. Należało odpiąć łańcuchy, zdjąć kolejne odcinki jezdni oraz załadować wszystkie ruchome części konstrukcji na tratwy i szkuty. Po podniesieniu kotwic cała flotylla popłynęła z prądem do Płocka. Kłopoty z ponownym ustawieniem mostu poniżej Płocka na Wiśle nastąpiły we wrześniu, kiedy armia wracała na lewy brzeg, gdzie została rozformowana. Król przybył wówczas do Przypustu 25 września i czekał cały następny dzień, ponieważ „z trudem udało się złożyć i umocnić most, który niegdyś, w czasie marszu króla do Prus ustawiono w pół dnia". W opisie tych trudności przy przeprawie w Przypuście (koło Aleksandrowa Kujawskiego) Długosz jest mało precyzyjny. Twierdzi, że Jagiełło musiał czekać tutaj 5 dni, czekał zaś tylko dzień. Kłopoty, które Długosz określił jako „utracenie przychylności losu" przez Jagiełłę, były przewidywalne. Nastąpiło typowe wezbranie wód Wisły w końcu września (tzw. michałówka). Szerokość nurtu Wisły przy Przypuście powinna wówczas być większa niż pod Czerwińskiem. Do budowy mostu trzeba było użyć więcej jednostek pływających i więcej przęseł ${ }^{42}$. Grupa cieśli i flisaków w Przypuście mogła tu być mniej liczna i mało wprawna; mogło też brakować materiału budowlanego.

Nośność i wytrzymałość mostu, mającego przyjmować przez 2-3 doby duże obciążenia, zależała od: wielkości, wyporności i wytrzymałości zbudowanych jednostek pływających (zapewne szkuty), stabilności konstrukcji zmontowanych na pokładach dla położenia przelotowej jezdni oraz długości i sprężystości (jakość i cechy budulca) przęseł zmontowanych nad wodą między łodziami. Oczywiście ważna była stabilność całej konstrukcji: rzucenie 4 kotwic z każdej jednostki i być może silne powiązanie łańcuchem (lub dwoma) wszystkich szkut, ustawionych w szereg od brzegu do brzegu Wisły.

Hipoteza o moście drewnianym opartym na 50 płaskodennych szkutach średniej wielkości jest zupełnie prawdopodobna. Jeżeli most przygotowywano przez półtora roku (od wiosny 1409 r.), to przede wszystkim należy podziwiać dyscyplinę i dyskrecję wykonawców oraz ludności starostwa radomskiego, od której informatorzy krzyżaccy nie uzyskali żadnych wiadomości przez okres kilkunastu miesięcy. Most był gotów na ok. 24 czerwca, niebawem spławiony pod Czerwińsk, gdzie zmontowany został zapewne 28-29 i przez przedpołudnie 30 czerwca. Sucha przeprawa przez Wisłę najbardziej potrzebna była taborom i artylerii. Pogląd o funkcjonalności mostu łyżwowego można uzyskać badając: rozmiary, ładowność i wagę typowego wozu taborowego (tzw. skarbowego) oraz typ i ciężar wiezionych armat. Masywne wozy nie miały ruchomego podwozia dla przednich kół, były trudne do manewru i musiały być ciągnione przez 3-4 konie (tzw. woźniki). Każdy wóz taborowy eskortowany przez 4 pachołków, kierowany był przez woźnicę jadącego na lewym koniu przy dyszlu. Dodatkowy koń bywał zaprzęgany z przodu, do końca dyszla, gdzie przyczepiano orczyk. Wóz i 3 konie, jako całość, osiągał długość ok. 8,75 m. Przyjmuje się, że skrzynia wozu skarbowego miała długość ok. 3,2 m i szerokość 1,8 m. Szerokość jezdni na moście musiała więc osiągać 3,5 m, dając możliwość manewru przy zaczepianiu o barierkę. Trzy konie pociągowe mogły swobodnie ciągnąć $500 \mathrm{~kg}$ ładunku, większe obciążenie stwarzało ryzyko wypadków i kłopotów ${ }^{43}$.

42 Ibid., ks. 10-11 sub anno 1410, s. 172; J. Gąsiorowski, Itinerarium, s. 72: Przypust 25 września, Raciążek 27 września.

43 J. Długosz, op. cit., ks. 10-11, passim; Z. Gloger, Encyklopedia staropolska, t. 3, Warszawa 1972, s. 242, 465, hasła: „skarbnik”, „woźniki”; A. Bołdyrew, Equus Polonus. Koń w wojsku polskim w XVI w., Piotrków 2016, s. 123-142. Przyjmując ładunek 500 kg, konia 600 kg, człowieka 80 kg, otrzymujemy 2620 kg. 
Artylerią polową, użyteczną także przy oblężeniach, były w początkach XV w. hufnice. Ich waga z lawetą osiągała $100 \mathrm{~kg}$. Używane na lawetach stałych, do obrony zamku czy przy oblężeniu, miewały także wagę przekraczającą $200 \mathrm{~kg}$. Dobrze zachowana hufnica znaleziona została w gruzach zamku Kurzętnik. Została ona zapewne zasypana podczas wojny w 1414 r. Może ona z pewnością reprezentować hufnice wiezione z taborem polskim przez most pod Czerwińskiem. Hufnica kurzętnicka jest starannie odlana z miedzi (z małymi domieszkami) i waży jedynie 42,28 kg. Hufnice wiezione w czerwcu 1410 r. na wojnę mogły być również większe (do $80 \mathrm{~kg}$ ), bo liczono się przecież z oblężeniami i szturmami zamków. Średniej wielkości hufnica (np. $80 \mathrm{~kg}$ wagi i $20-25 \mathrm{~cm}$ średnicy lufy) wyrzucała kamienne kule o „wielkości ludzkiej głowy”. Kula kamienna tej średnicy ważyła ok. 20 funtów, czyli 12 kg. Sto kul kamiennych „wielkości głowy” ważyto ok. $1200 \mathrm{~kg}$. Większe kalibry hufnic wystrzeliwały kule ważące $20-30 \mathrm{~kg}$. Za hufnicą musiał jechać co najmniej 1 wóz z kamienną amunicją; wiózł np. 50 kul dwudziestofuntowych („wielkości głowy”). Łączna waga takich 50 kul wynosiła 600 kg ${ }^{44}$. Oszacowania Nowaka dotyczące przeciętnej wagi konia $(650 \mathrm{~kg})$, uzbrojonego wojownika $(100 \mathrm{~kg})$ i wozu z ładunkiem $(700 \mathrm{~kg})$ są zawyżone, ale pozwalają ocenić obciążenie na moście w zależności, w jakiej liczbie i w jakich odstępach wjeżdżały wozy lub oddziały jazdy. Niektóre oszacowania ciężaru można dyskutować. Innej wagi był rumak bojowy rycerza, innej podjezdek, jeszcze mniej ważył woźnik (koń taborowy). Ciężar artylerii był również bardzo zróżnicowany. Prowadzone na wojnę hufnice nie ważyły zapewne więcej niż 90-200 kg. Pojedyncze sztuki ciężkiej artylerii czy machin oblężniczych mogły być spławione Wisłą ${ }^{45}$.

Zachowawczość i brak krytycyzmu w sprawie mostu postawionego na łodziach pod Czerwińskiem w ostatniej syntezie poświęconej wojnie 1409-1411 r. budzi zdziwienie. Pełna akceptacja informacji Długosza nie jest właściwa z kilku względów ${ }^{46}$. Proponujemy przyjąć nową rekonstrukcję wydarzeń, wysoce prawdopodobną ze względu na sekwencje czasowe oraz ówczesną technikę szkutniczą i flisacką. Brak szczegółowych źródeł pisanych należy zastąpić wiedzą o dawnej szacie leśnej Puszczy Radomskiej, warunkach hydrologicznych i topograficznych Wisły na odcinku mazowieckim oraz o szkutnictwie XV-wiecznym.

Decyzję o budowie mostu na łodziach pod Czerwińskiem podjęto stosunkowo wcześnie, zapewne zimą 1408 (np. 25 grudnia 1408 r.). Pobyt Jagiełły w Kozienicach i Jedlni (13-19 luty 1409 r.) mógł spowodować rozpoczęcie przygotowań. Most miał ułatwić i przyspieszyć wspólne działania wojsk polsko-litewskich. Tradycyjne forsowa-

44 P. Strzyż, Broń palna w Europie Środkowej w XIV-XV w., Łódź 2014, s. 84-90, 127-136, tutaj literatura i fotografie zabytkowych obiektów. Zob. też: M. Grodzicka, Bombarda z zamku w Kurzętniku, „Studia do Dziejów Dawnego Uzbrojenia i Ubiorów Wojskowych" t. 1, 1963, s. 7-13. Obiekt ten jest obecnie klasyfikowany jako hufnica.

45 T.M. Nowak, Uwagi o technice, s. 354.

46 K. Kwiatkowski, Koncentracja wojska; S. Jóźwiak, K. Kwiatkowski, A. Szweda, S. Szybkowski, op. cit., s. 304 i przypisy nr 318 i 319, w których uderza niezdecydowanie. 
nie rzek na przeprawach (promy) i brodami tworzyło oczywistą alternatywę. Zakres koniecznych prac do wykonania i wymogi techniczne spowodowały rozpoczęcie prac wiosną 1409 r. Już wówczas, wraz z mistrzem Jarosławem, zdecydowano o liczbie i typie jednostek pływających, potrzebnych do montażu mostu. Po pomiarach albo po wizji lokalnej pod Czerwińskiem ustalono niezbędną liczbę, zapewne 50 płaskodennych łodzi (szkut), które należało zbudować. Sprawa, czy to były szkuty, czy może promy, pozostaje do rozstrzygnięcia. Wymiary i liczba jednostek jest trudna do ustalenia. Dobre przygotowanie drewna dla cieśli i szkutników wymagało odpowiedniego suszenia. Puszcza Radomska dawała możliwość zgromadzenia odpowiednich asortymentów drewna. Mistrz Jarosław wybrał - zapewne w Małopolsce - ekipy szkutników i cieśli. Kowale mogli rozpocząć prace równolegle z budową łodzi (szkutnicy) i przęseł (cieśle). Powinni wykonać najmniej ok. 200 kotwic średniej wielkości, długie łańcuchy i ok. 75 tysięcy klamer szkutniczych.

Wiosną 1410 r. dokonano zapewne prób montażu, łącząc kilka segmentów mostu. Starosta radomski Dobrogost potrafił zorganizować pełną izolację od reszty kraju kilkuset wykonawców pracujących pod Kozienicami. Rygory tłumaczono zapewne królewskimi zakazami wstępu do puszcz, zarezerwowanych dla łowów władcy. Według uzgodnień wojna mogła być rozpoczęta po zachodzie słońca 24 czerwca. Po przedłużeniu rozejmu o 10 dni Jagiełło zawiadomił mistrza Jarosława polecając zmontowanie mostu. Spływ flotylli mostowej nastąpił najwcześniej w południe 26 czerwca. Most zaczęto stawiać najwcześniej o świcie 28 czerwca (sobota); ukończono około południa 30 czerwca (poniedziałek). Niewykluczone, że przez całą niedzielę (29 czerwca) odpoczywano. Wówczas montaż byłby wykonany wyjątkowo sprawnie, przez około półtora dnia. Most wytrzymał duże obciążenie, ale było ono dokonywane z rozwagą. Liczbę wszystkich przejeżdżających wozów taborowych i jezdnych można jedynie szacować. Wątpliwe, aby dopuszczono do wjechania na most zwartej kolumny taborowej. Informacje Długosza o pilnowaniu porządku przy przejeździe wojsk, dobitnie to potwierdzają ${ }^{47}$. Dalsze odkrycia średniowiecznych wraków i badania nad szkutnictwem średniowiecznym umożliwią uściślenie sformułowanych wyżej hipotez. W przedstawionej rekonstrukcji są elementy pewne, wysoce prawdopodobne i wiele zmiennych, zależnych od czynników niedających się jeszcze określić. Ten sam most zmontowano w lipcu 1414 roku pod Zakroczymiem, ale wysoka woda zmusiła wojska ciągnące znowu na wojnę z Krzyżakami do czekania przez 8 dni, aż wezbrana Wisła opadnie ${ }^{48}$

47 J. Długosz, op. cit., ks. 10-11, sub anno 1410, s. 76: „Przy wejściu na most wszyscy musieli przechodzić w jednakowym, wyznaczonym porządku z wozami, ludźmi i końmi". Ta informacja budzi zaufanie, może pochodzić od ojca lub stryja Długosza. Ile tysięcy jazdy i piechoty, ile tysięcy wozów i ile armat z amunicją mogło przejechać po moście - badacze dotąd nie ustalili. Zob. A. Nadolski, Grunwald 1410, Warszawa 1999, s. 61-62.

48 J. Długosz, op. cit., ks. 12, sub anno 1414, s. 33. 


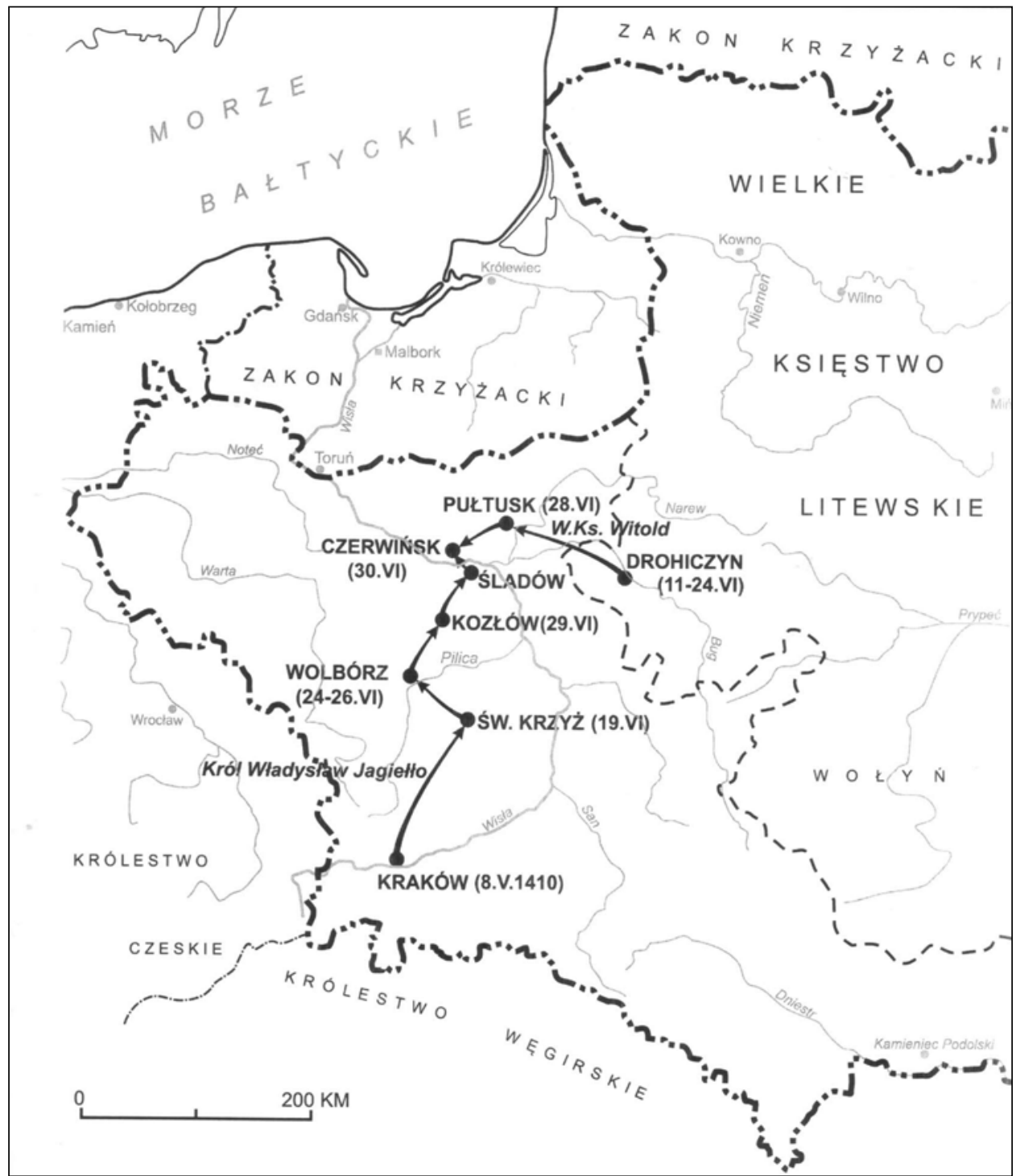

Ryc. 1. Drogi armii polskiej i litewsko-ruskiej zmierzających do koncentracji pod Czerwińskiem w 1410 r. (schemat opracowany przez autora). 


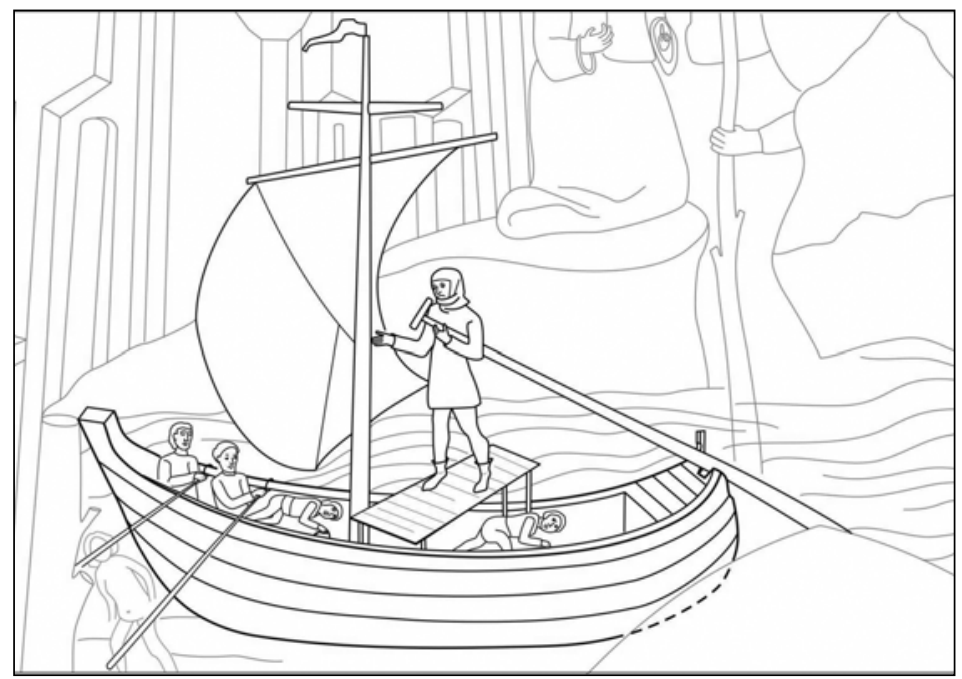

Ryc. 2. Wizerunek statku rzecznego z fresku w katedrze p.w. św. Jana Ewangelisty w Kwidzynie; z początku XV w. (rys. G. Zborowska-Znajkowska).

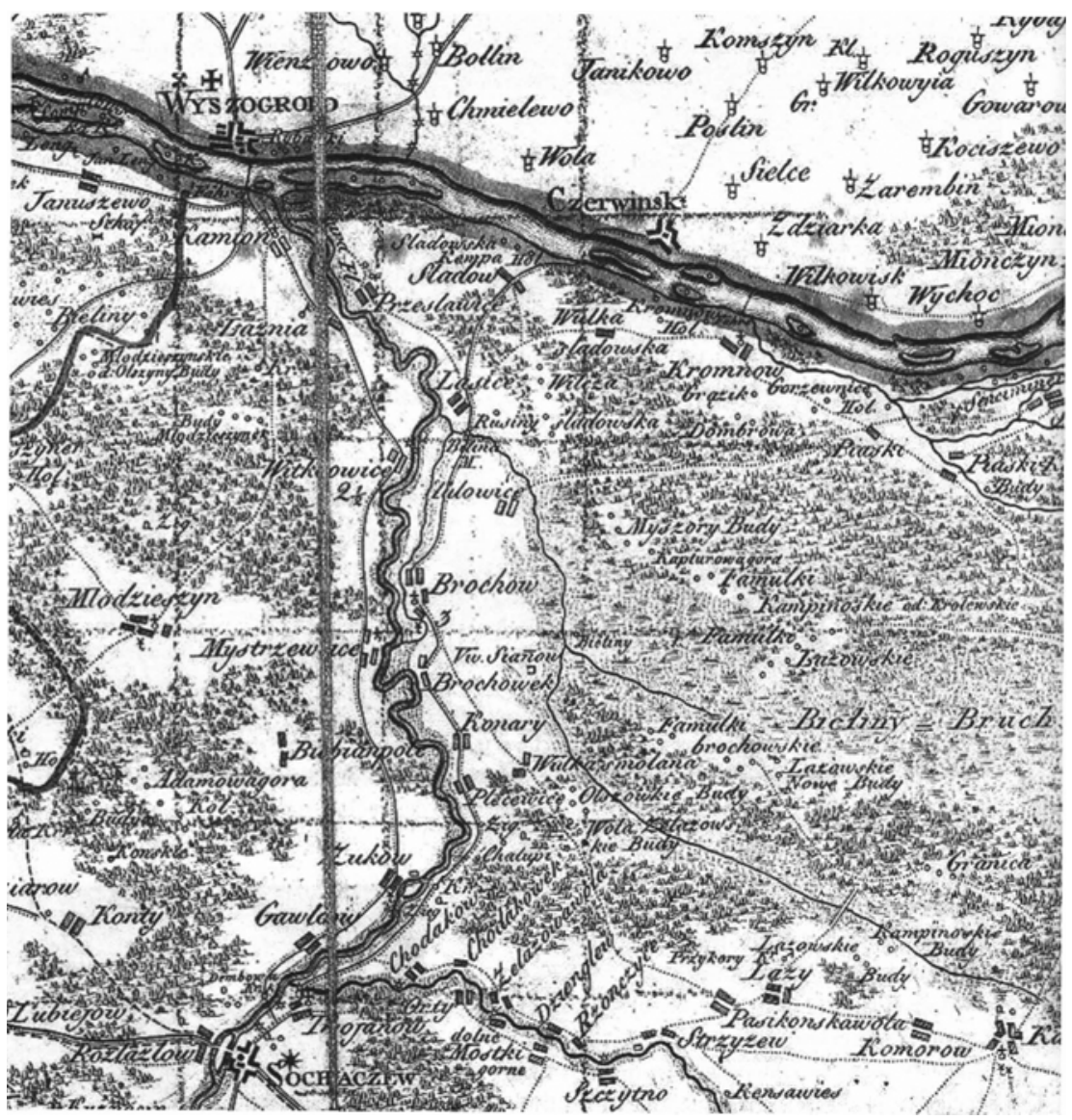

Ryc. 3. Miejsce przeprawy przez Wisłę ze Śladowa do Czerwińska. Mapa Prus południowych (fragment), oprac. D. Gilly, 1803-1805, skala: 1:150 000. 
Aneks

Zachowały się rachunki dotyczące konstruowania mostu łyżwowego, przygotowywanego na zjazd posłów i elekcję Władysława Wazy w Warszawie (wrzesień-listopad 1632 r.). Zobacz AGAD Warszawa/ekonomiczne nr 243, f. 255 do 277. Na ich podstawie opracowano publikację: B Hensel-Moszczyńska, O budowie mostu na elekcję $w$ roku 1632, „Almanach Muzealny” 2001, nr 3, s. 45-56. Rachunki są stosunkowo szczegółowe, ale niepełne. Dowiadujemy się z nich o kosztach (3000 florenów) i grupie organizatorów przedsięwzięcia, mniej dokładnie o liczbie i specjalnościach wykonawców. Byli tam dwaj cieśle i nadzorujący ich na miejscu mistrz, grupa traczy, 50 szkutników, różni okresowo zatrudniani pracownicy, najczęściej bez podania ich specjalności. Potrzeby dopełniano pracownikami bez kwalifikacji, oddziałem wojska i chłopami.

Budowa zaczęta w lipcu trwała do 26 września. Porównanie budowy mostu z 1409/1410 r. z mostem elekcyjnym z 1632 r. można dokonać tylko ogólnie. Porównać można: 1. planowanie i organizowanie budowy; 2. dobór pracowników, ale nie ich liczbę; 3. rozwiązania techniczne. Wszystko wskazuje, że w 1409 r. zaplanowano i wykonano lepiej i solidniej; oczywiście trwało to znacznie dłużej. Decyzja polityczna w 1632 r. narzuciła trudny okres dla wykonania mostu przez środkową Wisłę - późną jesień. W czerwcu 1410 r. mogła nastąpić jedynie parodniowa fala wyższej wody. Jesienią popłynęła wczesna kra. Organizatorzy elekcji większą wagę przywiązywali do zapewnienia finansów aniżeli do gromadzenia jednostek pływających, materiałów budowlanych i fachowców.

Konstruowanie mostu przebiegało chaotycznie. Żeby zdążyć z ukończeniem mostu na czas, pracowano o zmierzchu i w nocy przy zapalonych świecach. Nieudolnie i długo wynajmowano różnego typu jednostki pływające, kompletując potrzebną ich liczbę (29 do 30) w różnych portach nadwiślańskich. Ostatnie statki sprowadzono do Warszawy na kilka dni przed rozpoczęciem konwokacji. Budulec zgromadzono również bez ustalonego planu i różnej jakości. Były to belki i pnie różnej grubości, częściowo tylko okorowane (bale). Przęsła pomiędzy jednostkami pływającymi trzech typów (szkuty 11, statki 10, dubasy 8) miały zapewne różną długość i jakość, przeciętnie ok. $10 \mathrm{~m}$. Jedno przęsło było ruchome (zwodzone) ponieważ zapisano, że wykonano śluzę, do przepuszczania statków pływających po Wiśle.

Most był prowizoryczny i trzykrotnie psuł się podczas użytkowania (od 28 września do ok. 20 listopada). Przejechały po nim tylko grupy jezdnych oraz nieustalona liczba wozów chłopskich. Niekontrolowane obciążenie przy przepędzaniu stada wołów spowodowało uszkodzenie dwóch przęseł. Jednostki pływające z których zmontowano most w 1632 r. były umocowane przez dwojakie zabezpieczenia: uwiązanie do słupów wbitych kafarami w Wisłę oraz zarzucenie kotwic. Jest to wskazówka, że w 1410 r. postępowano zapewne podobnie. Dysponowanie w 1410 r. jednakowymi szkutami było warunkiem sukcesu. Precyzyjna konstrukcja z grubych desek i profilowanych belek umożliwiła trzykrotnie montowanie tego samego mostu wykonanego pod Kozienicami, dwukrotnie w 1410 r. i raz w $1414 \mathrm{r}$. 


\section{Bibliografia}

\section{Źródła}

Atlas historyczny Polski. Mazowsze w drugiej połowie XVI w., red. W. Pałucki, cz. 1-2, Warszawa 1973.

Cronica conflictus Wladislai regis Poloniae cum Cruciferis anno Christi 1410, [w] Monumenta Poloniae Historica, t. 2, wyd. A. Bielowski, Lwów 1872, s. 897-904.

Długosz J., Roczniki czyli Kronika Królestwa Polskiego, ks. 10-11, Warszawa 1982.

Mapa Prus Południowych, oprac. D. Gilly, 1802-1803, skala: 1:150.000.

Pazyra S., Najstarszy opis Mazowsza Jędrzeja Święcickiego, Warszawa 1974.

Zbiór dokumentów małopolskich, t. 6, wyd. S. Kuraś, Kraków 1972.

\section{Literatura przedmiotu}

Bartoszewicz A.. Handel solą na Mazowszu w XV i XVI w., "Rocznik Mazowiecki” t. 18, 2006, s. 47-62.

Biskup M., Wojny Polski z Zakonem Krzyżackim: 1308-1521, Gdańsk 1993.

Bołdyrew A., Equus Polonus. Koń w wojsku polskim w XVI w., Piotrków Trybunalski 2016.

Chlebowski B., Wisła, [w:] Słownik Geograficzny Królestwa Polskiego, t. 13, Warszawa 1893, s. 589-591.

Chwaściński B., Mosty na Wiśle i ich budowniczowie, Warszawa 1997.

Czapski M., Mosty drewniane, Warszawa 2001.

Domosławski J., Malarstwo ścienne na Pomorzu Wschodnim, [w:] Malarstwo gotyckie w Polsce. Synteza, Dzieje sztuki polskiej, t. 2, cz. 2, red. A.S. Labuda, K. Secomska, Warszawa 2004, s. 117-142.

Dorzecze Wisły. Monografia powodzi: maj-czerwiec 2010., red. M. Maciejewski i in., Warszawa 2011.

Dąbrowski J., Dawne dziejopisarstwo polskie (do 1480), Wrocław 1964.

Dybaś B., Walczak K, Toruńska przeprawa i mosty na Wiśle, Toruń 1998.

Ekdahl S., Grunwald, 1410. Studia nad tradycją i źródłami, Kraków 2010.

Falkowski E., Wisła mazowiecka, [w:] Wisła. Monografia rzeki, red. A. Piskozub, Warszawa 1982, s. 137-150.

Furtak K., Mosty drewniane. Podręcznik dla studentów wyższych szkół inżynierskich, Kraków 2002.

Gąsiorowski A., Nad nowym wydaniem „Roczników” Jana Długosza, „Przegląd Historyczny" t. 74, 1983, nr 1, s. 113-129.

Gąsiorowski A., Itinerarium króla Władysława Jagiełty: 1386-1434, Warszawa 2015.

Grodzicka M., Bombarda z zamku w Kurzętniku, „Studia do Dziejów Dawnego Uzbrojenia i Ubiorów Wojskowych" t. 1, 1963, s. 7-13.

Handelsman M., Historyka, Warszawa 1928.

Hensel-Moszczyńska B., O budowie mostu na elekcję w 1632 r., „Almanach Muzealny” 2001, nr 3, s. 45-56.

Jankowski J., Mosty w Polsce i mostownicy polscy. Od czasów najdawniejszych do koń. I wojny światowej, Warszawa 1973.

Jóźwiak S., Wywiad i kontrwywiad w państwie zakonu krzyżackiego w Prusach, Malbork 2004. 
Jóźwiak S., Rozwój badań nad wielką wojną polsko-litewsko-krzyżacką (1409-1411) w historiografii ostatniego półwiecza, "Komunikaty Mazursko-Warmińskie” 2009, nr 2, s. 209-222.

Jóźwiak S., Negocjacje pokojowe w trakcie trwania pierwszej fazy wojny polsko-krzyżackiej (16 VIII-8 X 1409), „Roczniki Historyczne” t. 79, 2013, s. 57-72.

Jóźwiak S., Kwiatkowski K., Szweda A., Szybkowski S., Wojna Polski i Litwy z Zakonem Krzyżackim w latach 1409-1411, Malbork 2010.

Jučas M., Grunwald 1410, Kraków 2010.

Kampinoski Park Narodowy: Dzieje Puszczy Kampinoskiej i okolic, t. 3, cz. 1, red. P. Matusak, Izabelin 2005.

Kobendzina J., Powodzie na Wiśle w okolicach Warszawy, "Gospodarka Wodna" t. 14, 1954, nr 4, s. 129-131.

Kolankowski L., Dzieje Wielkiego Księstwa Litewskiego, t. 1, Warszawa 1930.

Konopczyński W., Historyka, Warszawa 2012.

Kuczyński S., Wielka wojna z Zakonem Krzyżackim w latach 1409-1411, Warszawa 1980.

Kus J., Materiały do dziejów szkutnictwa w XVI-XVIII wieku w "Aktach miasta Kazimierza Dolnego”, „Kwartalnik Historii Kultury Materialnej” t. 32, 1984, nr 1, s. 23-38.

Laskowski O., Grunwald 1410, Londyn 1943.

Litwin J., Polskie szkutnictwo ludowe XX wieku, Gdańsk 1995.

Litwin J., Sztuka rzecznego szkutnictwa, „Rzeki” t. 9, 2000, s. 217-263.

Linde B.S., Słownik języka polskiego, t. 2, Lwów 1855.

Majewski M., Tillinger T., Roboty regulacyjne na Wiśle środkowej od 1919 do 1931, Warszawa 1932.

Morawski Z., O spławie wiślanym i przyczynach wojny 1409-1411, „Kwartalnik Historyczny" t. 95, 1988, nr 1, s. 107-111.

Morawski Z., Handel miast nadwiślanego Mazowsza do końca XVI w., [w:] Studia nad ośrodkami miejskimi $w$ dorzeczu środkowej Wisły, red. J. Łukasiewicz, Warszawa 1996, s. 7-31.

Nowak T.M., Uwagi o technice budowy mostów polowych w Polsce w XV do XVII wieku, "Studia i Materiały do Historii Sztuki Wojennej” t. 2, 1956, s. 345-387.

Nowak T.M, Polska technika wojenna XVI-XVIII wieku, Warszawa 1970.

Olejnik K., Działalność militarna Polski w czasach Kazimierza Wielkiego, Poznań 1966.

Ossowski W., Przemiany w szkutnictwie rzecznym w Polsce. Studium archeologiczne, Gdańsk 2010.

Ossowski W., Krąpiec M., Niektóre zagadnienia szkutnictwa późnośredniowiecznego na przykładzie wraka z Kobylej Kępy, „Przegląd Archeologiczny” t. 49, 2001, s. 85-101.

Pacuski K., O rodzie Gozdawów na Mazowszu w XIV-XV w. i jego tradycjach, [w:] Kultura średniowiecza i staropolska. Studia ofiarowane A. Gieysztorowi, Warszawa 1991, s. 655-665.

Pacuski K., Współpracownicy książąt mazowieckich w ziemi warszawskiej w XIV w., [w:] Początki Warszawy. Spojrzenie po 700 latach, red. H. Rutkowski, Warszawa 2015, s. $53-72$.

Pazyra S., Geneza i rozwój miast mazowieckich, Warszawa 1959.

Poklewski-Koziełł T., Zamki królewskie i miasta obronne na drogach handlowych prowadzących przez Polskę nad Morze Bałtyckie w XIV i XV w., [w:] Studia o zamkach średniowiecznych, red. T. Poklewski-Koziełt, Warszawa 2012, s. 99-108. 
Polska technika wojskowa do 1500 roku, red. A. Nadolski, Warszawa 1994.

Potkowski E., Fikcja i historia u Długosza, „Przegląd Humanistyczny” 1987, nr 12, s. 47-63.

Reszka A., Żaglowce frachtowe z Czerwińska n. Wisłą, "Kwartalnik Historii Nauki i Techniki" t. 49, 2004, nr 2, s. 69-112.

Reszka A., Wiślane statki i techniki nawigacyjne od XVI do XX wieku, Gdańsk 2012 (Prace

Centralnego Muzeum Morskiego, Seria A, t. 13).

Rola militarna Wisły w dziejach Polski, cz. 1, Od czasów piastowskich do 1864, red K. Myśliński, Warszawa 1992.

Rosset A., Drogi i mosty w średniowieczu i czasach Odrodzenia, Warszawa 1974.

Rymsza B., O budowie repliki mostu Jagiełty, [w:] Wsparcie inżynieryjne w wielkiej wojnie z Zakonem Krzyżackim 1409-1411. Sesja popularno-naukowa z okazji 600-lecia bitwy pod Grunwaldem w 1410 roku, red. M. Białas, Warszawa 2010, s. 31-40.

Samsonowicz H., Gospodarka i społeczeństwo XIII-pocz. XVI w., [w:] Dzieje Mazowsza,

t. 1, do 1526, red. A. Gieysztor, H. Samsonowicz, Pułtusk 1994, s. 249-293.

Smolarek P., Stan i perspektywy badań nad rozwojem szkutnictwa w Polsce (do końca XVIII w.), „Kwartalnik Historii Kultury Materialnej” t. 7, 1959, nr 2, s. 229-267.

Smolarek P., Zabytki szkutnictwa skandynawskiego, Gdańsk 1963.

Studia geograficzne nad aktywizacją małych miast, red. K. Dziewoński, Warszawa 1957.

Stachý J., Fal B., Dobrzyńska I., Hołdakowska J., Wezbrania rzek polskich w latach 1951

1990. Materiały Badawcze, Warszawa 1996 (Hydrologia i Oceanografia, nr 20).

Strzyż P., Broń palna w Europie średniowiecznej w XIV-XV w., Łódź 2014.

Tyszkiewicz J., Geografia historyczna. Zarys problematyki, Warszawa 2014.

Tyszkiewicz J., Klęski elementarne na Mazowszu w XVI-XVIII w. [w:] Dzieje Mazowsza,

t. 2, 1527-1795, red. J. Tyszkiewicz, Pułtusk 2015, s. 293-309.

Ważny T., Dendrochronologia obiektów zabytkowych w Polsce, Gdańsk 2001.

Wilska M., Mazowieckie środowisko dworskie Janusza Starego. Studium społeczne, Warszawa 2012.

Wyrozumski J., O kongregacji włóczków krakowskich, „Małopolskie Studia Historyczne” t. 1, 1958, nr 1, s. 29-43.

Wyrozumski J., Państwowa gospodarka solna w Polsce do schyłku XIV w., Kraków 1968.

Z biegiem Wisły, red. C. Kolago, Warszawa 1967.

Zobel H., Alkhafaji Th., Mosty drewniane. Konstrukcje przełomu XX i XXI wieku, Warszawa 2006.

prof. dr hab. Jan Tyszkiewicz, absolwent studiów historycznych oraz archeologii w Uniwersytecie Warszawskim. Pracownik Instytutu Historycznego UW w latach 1962-2009, Akademii Humanistycznej w Pułtusku od 1994 r. Mediewista i nowożytnik. Bada Polskę i Słowiańszczyznę średniowieczną: dzieje, kulturę, wojskowość oraz historię koczowników w Europie. Zajmuje się geografią historyczną, dawnym środowiskiem geograficznym. Autor przeszło 400 publikacji, w tym 13 monografii. e-mail: etyszk@gmail.com

Data zgłoszenia artykułu: 19 grudnia 2019

Data przyjęcia do druku: 5 czerwca 2020 